\title{
AZ ÖNKÉNTES GYERMEKTELENSÉG PSZICHOLÓGIÁJA: SZAKIRODALMI ÁTTEKINTÉS
}

\author{
KIS ANDREA \\ Debreceni Egyetem, Pszichológiai Intézet \\ E-mail: andrea.kis@aggiemail.usu.edu
}

Beérkezett: 2017. szeptember 4. - Elfogadva: 2018. augusztus 21.

Jelen elméleti fókuszú tanulmány az önkéntes gyermektelenség jelenségkörének pszichés és szociológiai vonatkozásairól szóló jelentôsebb kutatások eredményeit foglalja össze mind nemzetközi, mind hazai kutatásokat alapul véve. Szisztematikus kulcsszókeresés módszerével elsôsorban az angol nyelvúu adatbázisokban elérhetố tanulmányok kerültek áttekintésre, de a magyar szakirodalom is felhasználásra került.

A téma napjaink társadalmi változásainak egyik fontos és sokszinü eleme, mégis periférikus helyzetünek nevezhetố. Hazánkban szinte egyáltalán nem, míg a nemzetközi szakirodalomban igen mozaikosan jelenik meg - nagy idôbeli és térbeli eltérések akadnak egy-egy vizsgálat vagy tanulmány megjelenése között. Emiatt jelen írás céljai közé tartozik az is, hogy ezen paraméterek figyelembevételével egységesebb képet alkothassunk nem csupán magáról a témáról, de a téma kutatási hátterének jelen helyzetéról is.

A szakirodalmi háttér figyelembevételével egyértelmünek tünö következtetés az, hogy a gyermektelenség mellett határozók olyan speciális csoportot alkotnak a gyermektelenek között, mely közel sem homogén, mégis bizonyos specifikus pszichés és szociáldemográfiai jellemzók mentén jól differenciálható. Nehéz azonban ezen a csoporton belül kategóriákat felállítani és a pontos fogalmi háttér tekintetében is megoszlanak a vélemények. Elmondható az is, hogy gyerekcipóben jár a jelenség hazai vizsgálata - magyar szerzók eddig elsôsorban szociológiai vagy demográfiai megközelitéssel vizsgálták a jelenségkört.

A pszichés ok-okozati mechanizmusokat feltárni hivatott vizsgálatok kicsiny száma és eredményeik fragmentáltsága szintén nehézzé teszi a téma személyiséglélektani és fejlődéslélektani vetületeiról való érdemi gondolkodást. Ami a szociálpszichológiai megközelitést illeti, a pronatalista társadalmak által devianciának interpretált gyermekmentesség társadalmi elfogadására és a stigmák eltörlésére irányuló lehetôségek vizsgálata kevéssé kutatott téma, de egyes tanulmányok felvetik ennek szükségességét. A magyarországi gyakorlatban mindez ma még nem magától értetôdō.

Összességében a tanulmány célja a fentebb körvonalazott eredmények ismertetése, valamint a további, a témába vágó pszichológiai kutatások ösztönzése.

Kulcsszavak: önkéntes gyermektelenség, gyermekvállalás, gyermektelen, gyermekmentes, anyai szerep 


\section{BEVEZETÉS}

Jelen tanulmány a gyermektelenség mellett határozók pszichológiai és demográfiai jellegzetességeinek, illetve a társadalom velük kapcsolatos nézeteinek rövid, összefoglaló jellegú és fơként pszichológiai fókuszú leírása. Az önkéntes gyermektelenség vizsgálata több szempontból is nagy társadalmi jelentôséggel és aktualitással bír.

Elmondható ez egyfelôl azért, mert az utóbbi évtizedekben a fejlett társadalmakban megnövekedett a gyermektelenek aránya, és az ezzel a jelenséggel foglalkozó kutatások száma is követte ezt a változást. Emellett egyes országokban az önkéntesen gyermektelenek aránya akár a 15\%-ot is meghaladhatja az utóbbi évtizedek ideológiai változásainak következtében (Pongrácz, 2007).

Másrészt az utóbbi évtizedekben a társadalmi nemekkel kapcsolatos egyetemi tanulmányi lehetôségek száma a nyugati országokban és különösen az USA-ban rohamosan növekedni kezdett. Ezt a tendenciát követve a témát különbözô szempontokból körüljáró tudományos írások száma is növekedésnek indult, egy új szemlélet kibontakozásának lehettünk tanúi. Magyarországon ezek a változások csak az utóbbi években indultak meg, és gyakran ütköztek igen erôs ellenállásba. A közvéleményt meghatározó féligazságok és az akadémiai körökben még mindig elterjedt, hagyományos nemi szerepeket alternatívanélküliként aposztrofáló, normalizáló írások egyaránt felelôsek lehetnek a lassú és nehézségekkel teli átmenetért. Éppen ezért kiemelten fontos a kapcsolódó tudományos témák objektív megközelítése és minél precízebb értése, a tévhitek eloszlatása és a kapcsolódó problémák elemzó vizsgálata.

Ennek érdekében mindenekeloott felvezetésre kerülnek a témakört meghatározó fogalmak. Fontos kiemelni, hogy az önkéntesen gyermektelenek és egyéb okból gyermek nélkül maradó társaik között számtalan különbség tárható fel mind demográfiai, mind pedig pszichológiai szempontból, így a két fogalom nem felcserélhetô (Dariotis, 2004). A pontos definiálás és az - egyébként egyáltalán nem homogén csoportot alkotó - gyermekmentes személyek további kategorizációja több problémát is felvet, így megjelenik például döntésük lezáratlanságának dilemmája a szakirodalomban (Szalma és Takács, 2012).

Jelen témához kapcsolódik napjaink Európájának szociológiai szempontból meghatározó kérdése és gyakran emlegetett problémája, a demográfiai csökkenés is. Az elmúlt néhány évtized során a legtöbb európai ország teljes termékenységi arányszáma visszaesett, vagyis alacsonyabb az a hipotetikus gyermekszám, melyet egy nô szülne egész élete folyamán, amennyiben az adott évi gyakoriság egész életére állandósulna. Európában ez a szám jelenleg alacsonyabb a népesség reprodukcióját biztosító 2,1-es szintnél (Szalma, 2010). A „második demográfiai átmenet” kifejezést, illetve az ehhez kapcsolódó késôbbi kutatási eredményeket használva a szociológusok több, közel egy idôben megjelenô és egymásra hatással levô okra vezetik vissza ezeket a változásokat. Ilyen okok a termékenység és halandóság alacsony szintjei, a különbözô modern értékrendi változások, a házasságok számának csökkenése és a válások számának növekedése, a nôi munkavállalás, valamint a fogamzásgátló módszerek elterjedése (Tárkányi, 2008).

Magyarország helyzete hasonló a fentebb ismertetett zsugorodó társadalmú országokéhoz. A második demográfiai átmenet országunkat az 1990-es években érte el, és 
jelenségei máig aktívan jelen vannak a magyar társadalomban (Tárkányi, 2008). A magyar termékenységi mutató 2013-ban 1,3 volt, és noha a magyar nôk általában több gyermeket szeretnének, ilyen irányú elképzeléseik gyakran nem vagy csak részben valósulnak meg (Szalma és Takács, 2016). Ellentétben több európai országgal, melyekben a termékenységi trendek visszájukra fordultak és lassú növekedést mutattak, Magyarország termékenysége az utóbbi években is stagnált, és a hosszú távú eloorejelzô modellek is a népesség fogyását jósolják (Földházi, 2013).

A téma szempontjából azonban nem csupán a különbözó országok népességszámának alakulása fontos, az adott társadalom népesedéssel kapcsolatos szemlélete is legalább ilyen nagy jelentôséggel bír. Történelmileg és napjaink népesedéspolitikai és közvéleményt befolyásoló kormánypolitikai elképzeléseit tekintve egyaránt elmondható, hogy Magyarország a pronatalista szemléletú országok közé tartozik, értékrendje gyermekcentrikus, és a többségi vélekedés szerint a teljes élethez minden nônek szüksége van gyermekre (Kollega Tarsoly, 1997; Szalma és Takács, 2016; Pongrácz, 2007). Ezek alapján a termékenység növekedését a közvélemény szükségesnek és kedvezőnek ítéli, különösen a fentebb leírt csökkenési tendenciák ismeretében.

A fertilitás csökkenéséhez kapcsolódó, az utóbbi években egyre nagyobb figyelemre szert tevô témakörök a kései vagy halasztott gyermekvállalás és a gyermektelenség is. Pongrácz (2007) kutatása rávilágít arra az elterjedt hiedelemre, mely szerint a népességszám csökkenése leginkább a gyermekvállalás halasztásával magyarázható, míg Szalma és Takács (2016) összegzése alapján közhiedelem az is, hogy az önkéntesen gyermektelenek aránya növekedố tendenciát mutat. Az elsố elképzelés igazoltnak látszik, hiszen a gyermekvállalást halasztó, idôsebb korosztályba tartozó nôk közül valóban aránylag kevesen válnak késôbbi életük során anyává. Ezzel szemben az önkéntesen gyermektelenek száma nem mutat jelentôs változást, Magyarországon arányuk még mindig csupán 2\% körüli (Szalma és Takács, 2016).

Noha az önkéntesen gyermektelen nôk jelenleg viszonylag alacsony számban vannak jelen hazánkban, helyzetük egyedisége pszichológiai szempontból mindenképpen figyelemre méltó. Mind személyiségjellemzőik, motivációik és fejlôdéslélektani sajátosságaik, mind pedig az óket közvetlenül vagy közvetve érintô, döntésükkel szoros kapcsolatban álló szociálpszichológiai hatások alapján feltételezhetô, hogy a kérdéskör gazdag kutatási anyaggal szolgálhat. Az eddigi vizsgálatok alapján ok-okozati kapcsolatokról nem beszélhetünk egyértelmúen a legtöbb esetben, s bár akadnak a gyermekvállalási motivációk genetikai (Miller, 2011, McAllister, Pepper, Virgo és Coall, 2016), fejlôdéslélektani (Miller, 1992) és személyiséglélektani (Houseknecht, 1979, Miller, 1992, Avison és Furnham, 2015) hátterére reflektáló vizsgálatok, sok esetben ezek sem szolgálnak egyértelmú válaszokkal.

Szó esik továbbá a téma szempontjából kiemelten releváns előítéletekrôl és sztereotípiákról is. Ahogy a fentiekbôl kitúnhetett, a cikk elsôsorban az önkéntesen gyermektelen nôkre vonatkozó kutatási adatokat foglalja össze. Tudatos választásuk egy erôsen gyermekcentrikus társadalmon belül megkülönböztetéssel, stigmatizációval járhat, s a tradicionális nôi szerepnek számító anyaszerep elhagyásával pszichés fejlốdésük is egészen sajátos jellemzókkel teli. A gyermektelenség mellett határozó nóket a rájuk irányuló előítéletek miatt, különösen a pronatalista társadalmakon belül megannyi pszichológiai nehézség és ártalom érheti (Park, 2002). 
Az önkéntes gyermektelenség témája igen összetett és korántsem értéksemleges, a hozzá kapcsolt ideológiák és értékek a vizsgálat tárgyaira ugyanúgy hatással lehetnek, mint magára az ôket körülvevô társadalomra. Említést érdemel az összegzést szintén nehezítô, mozaikos és nehezen integrálható szakirodalmi háttér is. Ugyan a témához egyre gyarapodó számú kutatás és vizsgálat kapcsolódik, számuk még mindig elenyészô, különösen alacsonynak mondható az önkéntesen gyermektelen férfiak lélektani és egyéb jellegzetességeire reflektáló kutatási anyagok száma. A már megjelent kutatások pedig mind idôbeli, mind térbeli sajátosságaik alapján nagy eltéréseket mutatnak. Sok esetben érdemes ezért a feldolgozott írásokat és módszertanukat kritikai szemlélettel tanulmányozni, eredményeiket az adott kor és kulturális közeg jellegzetességeinek ismeretében értelmezni. Jelen dolgozat terjedelmi megkötései miatt itt leginkább ezen ismeretanyag informatív leírása valósulhatott meg, ám ezen túlmenôen több ponton rövid kritikai vagy értelmezó észrevételek és egy, a fontosabb szakirodalmi tételek és kutatások adatait összegzô táblázat (1. táblázat) hivatott segíteni az olvasót saját konklúzióinak levonásában.

\section{MÓDSZERTAN}

A jelen íráshoz felhasznált szakirodalmi anyag gyújtésének alapját szisztematikus kulcsszókeresés adta. Ezzel együtt a kész anyag nem tekinthetô a téma teljes szakirodalmát feldolgozó írásnak, ennek elsôdleges célja a téma magyar nyelvú ismertetése volt. A megfelelő angol és magyar nyelvú kulcsszavak (a fogalmi részben bemutatott szóhasználatban) segítségével történô szisztematikus gyújtés után szelekcióra került sor, melynek során a téma mélyebben feltárt, de meglehetôsen általános egységeit (fogalmi és demográfiai sajátosságok, személyiségjellemzók és motivációk, fejlôdéslélektan, stigmatizáció és sztereotípiák) érintô jelentősebb szakirodalmi munkák kerültek kiemelésre, és a cikk az ezekhez kapcsolódó elméleti és empirikus eredményekkel integrálva mutatja be ôket. A szakirodalmi gyújtés során elôször angol nyelvú tematikus kulcsszókeresésre került sor. A lehetséges kulcsszavak közül először a „voluntary childlessness" kifejezés került szúrésre, mivel ez a szakirodalomban leggyakrabban megjelenô és a jelenséget leginkább lefedő szókapcsolat. Emellett felhasználásra kerültek ennek gyakran előforduló, az irodalomban sokszor szinonímaként használt megfelelôi is; a „childless by choice”, „intentionally childless” és „childfree” kifejezések. A kulcsszavakkal történô keresésre négy nemzetközi adatbázisban kerültsor (PsycINFO, SocioINFO, Web of Science, Scopus). Az elsôdleges kulcsszóra a PsycINFO 92, a SocioINDEX 138, a Web of Science 154, a Scopus pedig 221 találatot adott - a másodlagos kulcsszavak alkalmazása után, összesen a négy adatbázisból 585 dokumentum került áttekintésre.

Magyar nyelven aránylag kevés a témát központi szerepben tárgyaló szakirodalmi írások száma. Ebben az esetben a vonatkozó elsôdleges kulcsszavak használatával (önkéntes/tudatos/akaratlagos gyermektelenség, gyermekmentesség, gyermekmentes) lényegesen kevesebb találat volt elérhetô, ezért a keresést egyéb kulcsszavakkal kellett kiegészíteni (gyermektelenség, gyermektelen). Az utóbbi két kulcsszó esetében csak a téma szempontjából valóban releváns dokumentumok kerültek kiválasztásra. Elenyészô számú orvosi értekezés, néhány pszichológiai témájú cikk és valamivel több demográfiai írás foglal- 


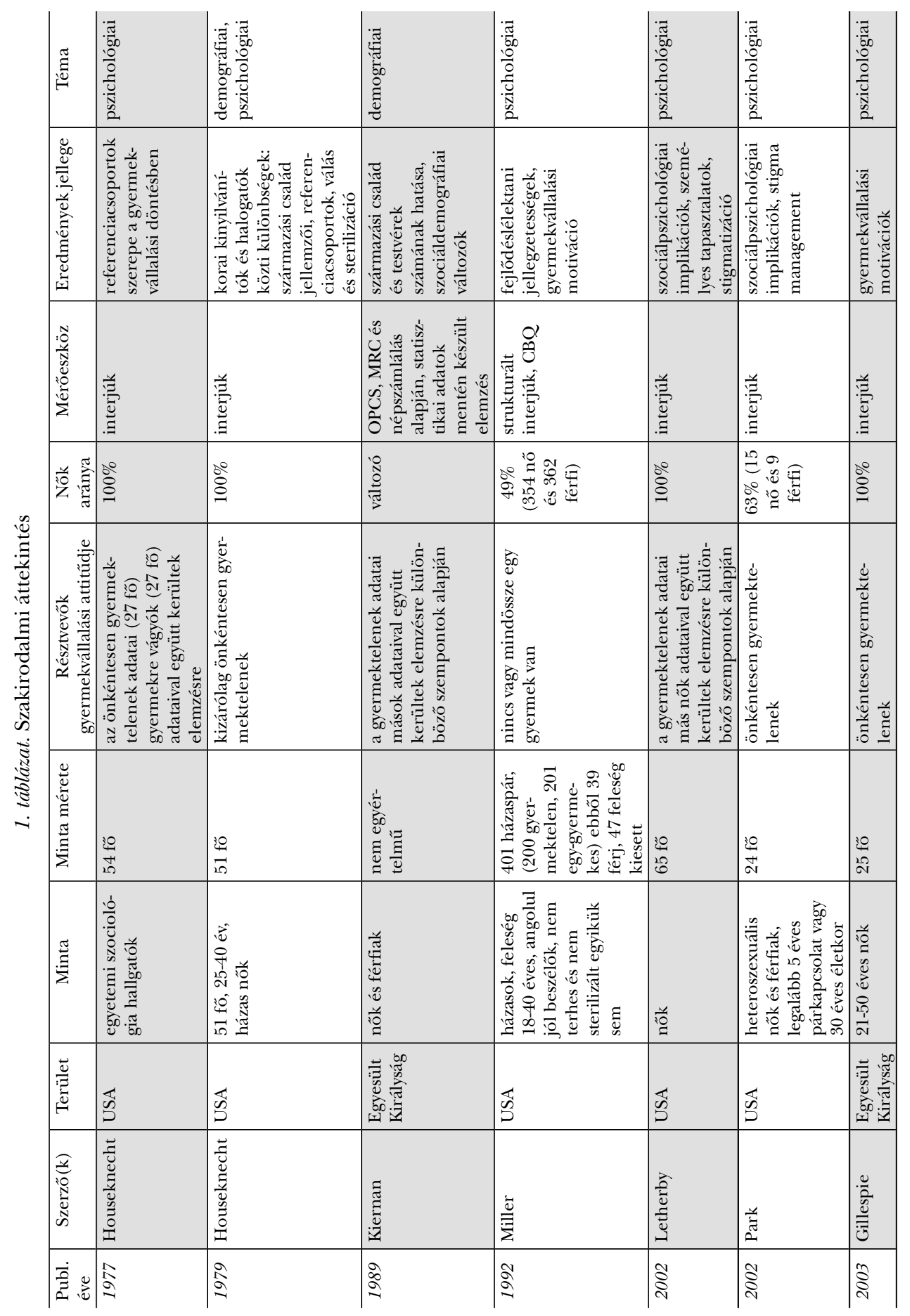




\begin{tabular}{|c|c|c|c|c|c|c|c|}
\hline 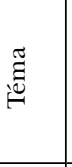 & 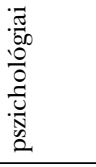 & 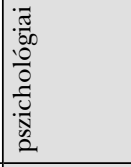 & 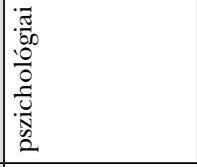 & 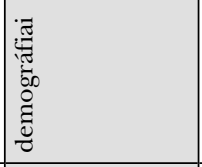 & 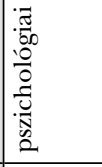 & 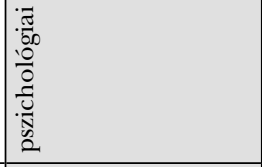 & 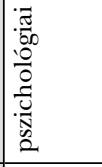 \\
\hline 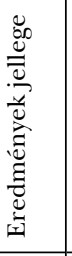 & 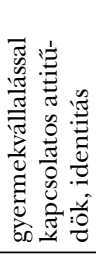 & 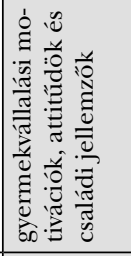 & 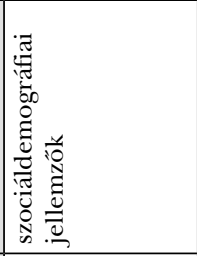 & 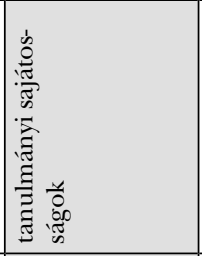 & 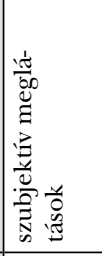 & 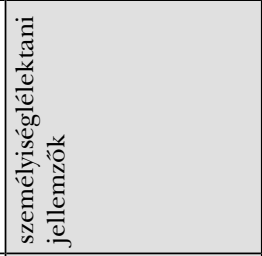 & 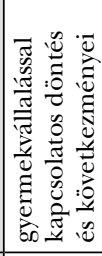 \\
\hline 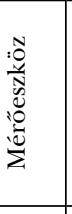 & 鸹 & 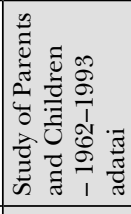 & 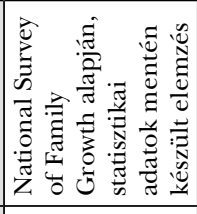 & 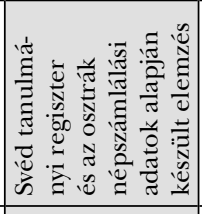 & 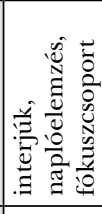 & 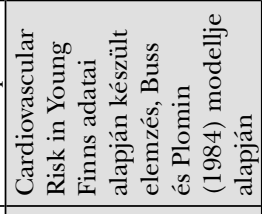 & 泀 \\
\hline 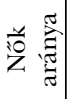 & $\stackrel{8}{8}$ & 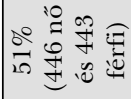 & $\stackrel{\circ}{8}$ & $\stackrel{80}{8}$ & $\stackrel{\circ}{8}$ & 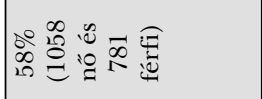 & $\stackrel{\circ 0}{8}$ \\
\hline 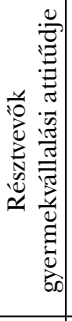 & 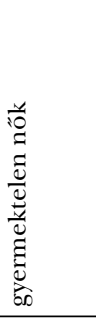 & 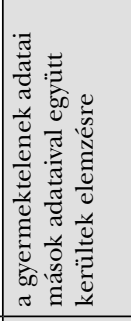 & 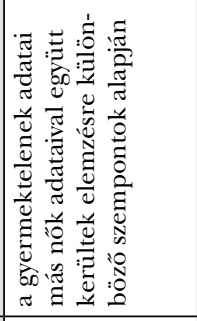 & 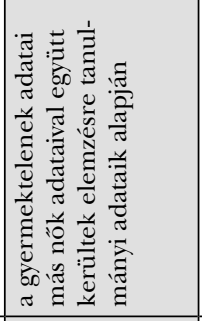 & 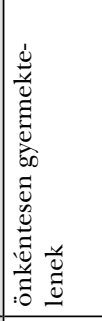 & 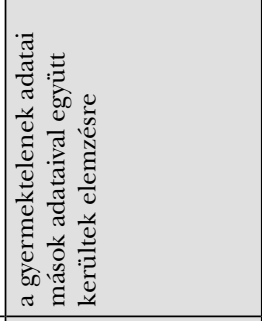 & 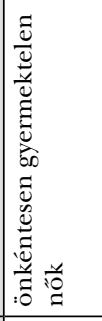 \\
\hline 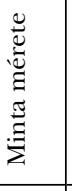 & $\begin{array}{l}10 \\
10 \\
\infty\end{array}$ & $\begin{array}{l}10 \\
0 \\
\infty \\
\infty \\
\infty\end{array}$ & 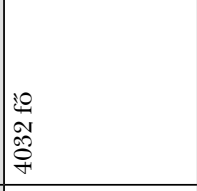 & 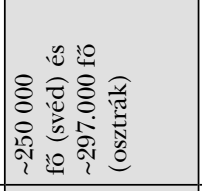 & 0 & 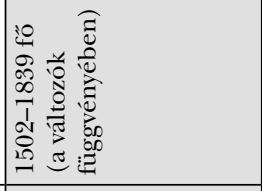 & $\begin{array}{l}30 \\
0 \\
0 \\
\end{array}$ \\
\hline$\stackrel{\frac{\pi}{3}}{\Sigma}$ & 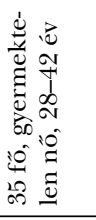 & 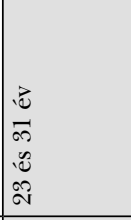 & 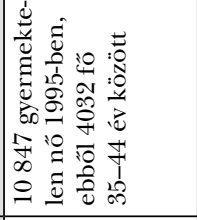 & 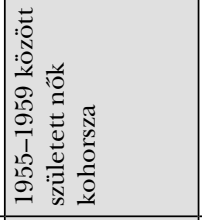 & 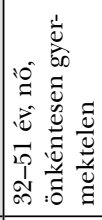 & 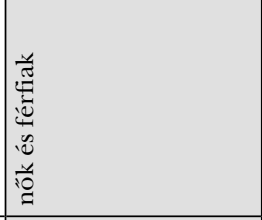 & 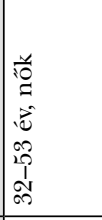 \\
\hline 峁 & 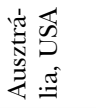 & 芯 & 岕 & 然 & 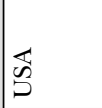 & 竞 & 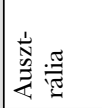 \\
\hline 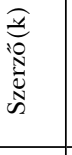 & 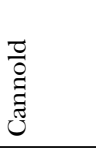 & 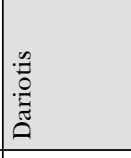 & 迅 & 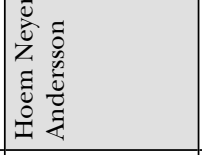 & 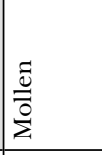 & 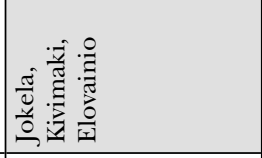 & 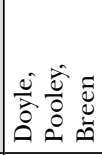 \\
\hline $\begin{array}{ll}\dot{0} & \\
\ddot{\Xi} & 0\end{array}$ & 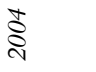 & $\underset{8}{2}$ & $\stackrel{2}{8}$ & $\stackrel{2}{\circledR}$ & $\underset{2}{2}$ & ஓे & $\underset{\sim}{\stackrel{\sim}{\sim}}$ \\
\hline
\end{tabular}




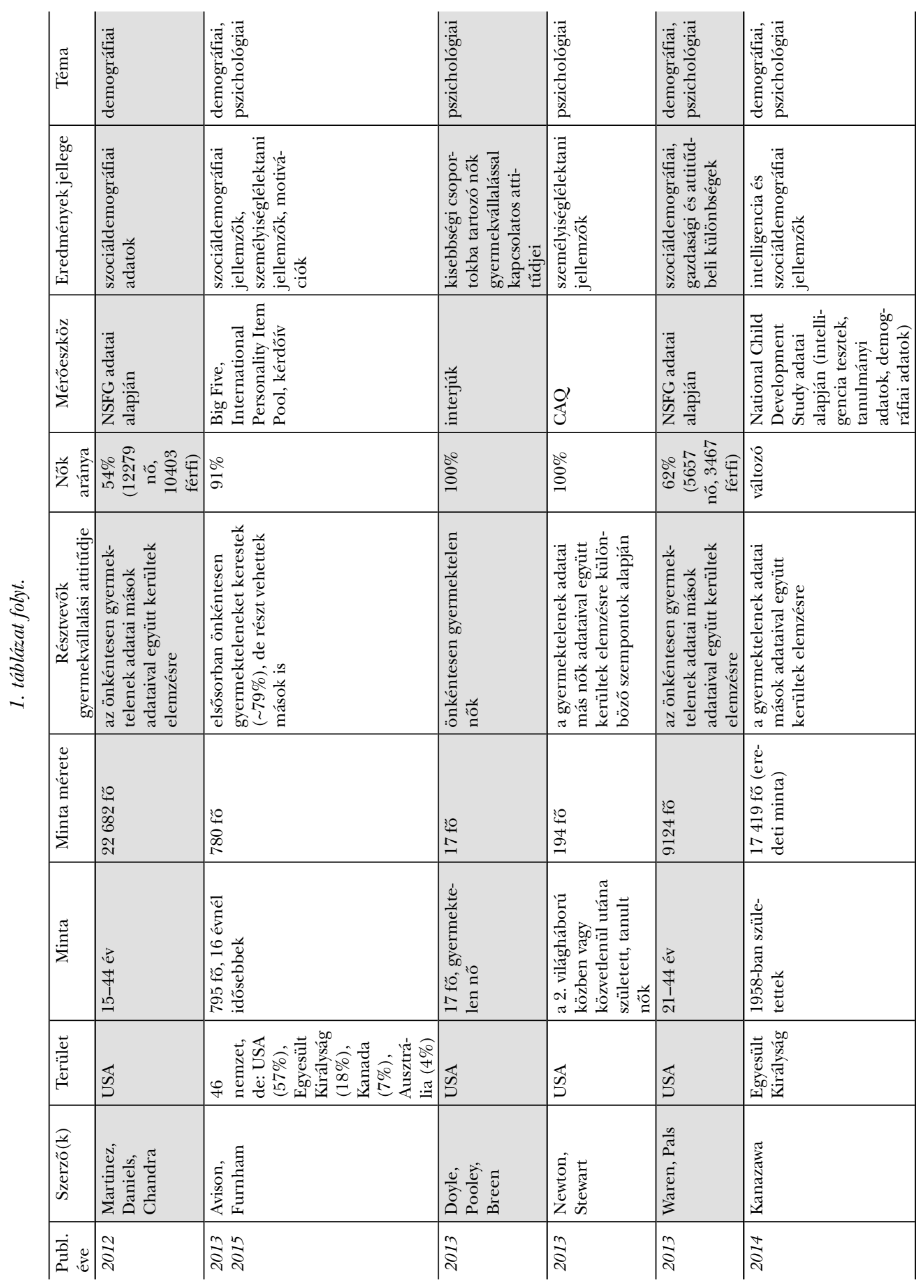




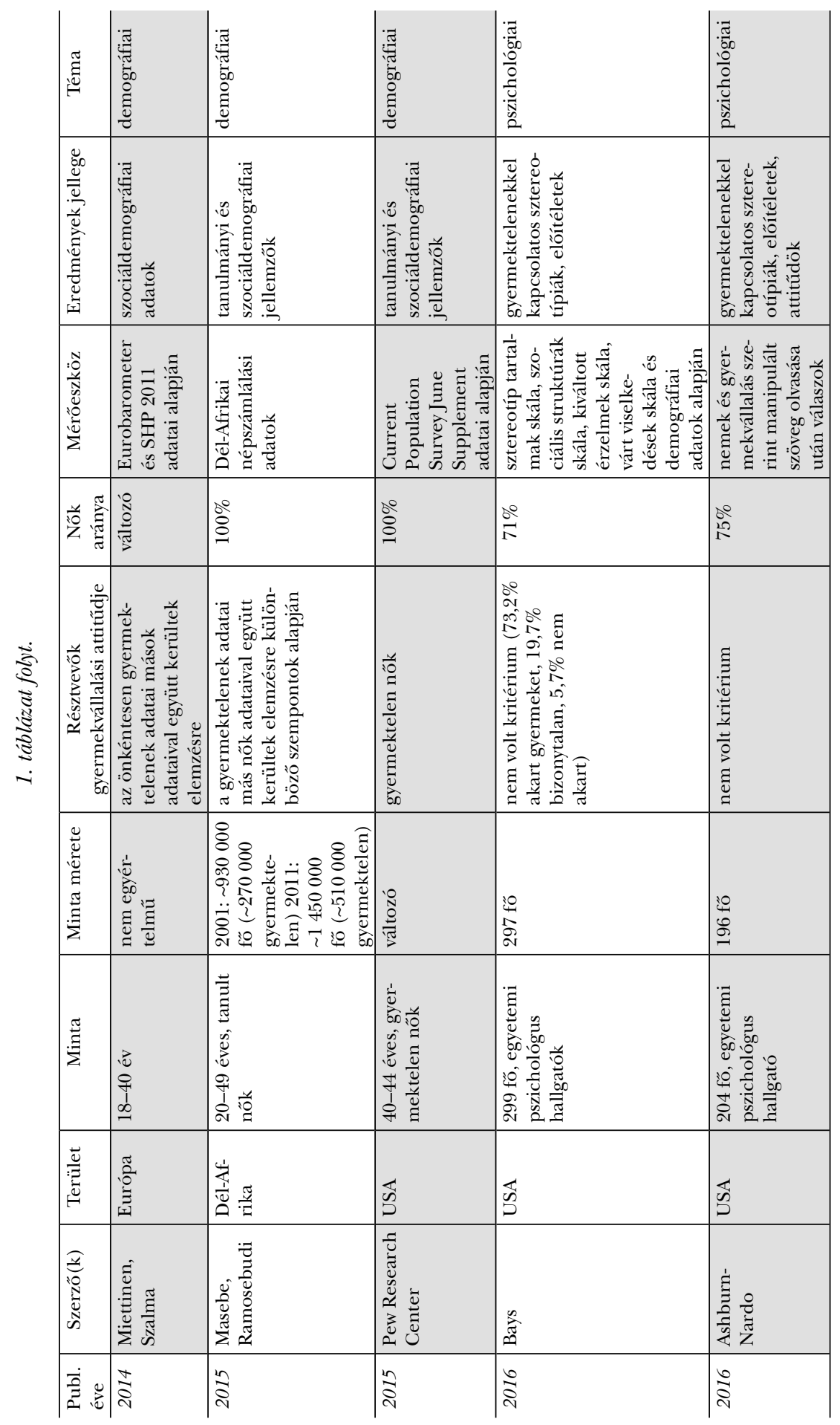


kozik magyar nyelven az önkéntes gyermektelenség témakörével. Ezek az általános keresôoldalak mellett a témaspecifikus adatbázisokban is szúrésre kerültek (MATARKA, MTMT, Arcanum, KSH, Demográfia, Akadémiai Kiadó, Magyar Tudomány, Google Scholar), majd az irreleváns vagy kevésbé releváns dokumentumok elhagyásával öszszesen 27 írás került áttekintésre. Jelen összefoglaló elkészítése során tehát ezek a találatok, illetve szükség esetén az ezeket kiegészítô források kerültek feldolgozásra. Így összesen 612 dokumentum került áttekintésre, ezek közül került kiemelésre a téma ismertetésének magját adó 25 tanulmány (1. táblázat), illetve a jelen publikáció megírásához felhasznált összesen 71 forrás. Az összes vizsgált adatbázis találatai kapcsán elmondható, hogy elsôsorban szakcikkek alkotják a téma szakirodalmának magját ezek vannak legnagyobb arányban és a leggyakrabban idézett források között. Ritkábbak a könyvfejezetek és még kevesebb alkalommal fordulnak elő a gyermekmentesség irodalmával foglalkozó könyvek.

A szakirodalom idóbeli eloszlása egyenetlen; bár a huszadik század elsô felére tehetôek az elsố kapcsolódó publikációk, ezek száma gyakorlatilag elhanyagolható. Fellendülés figyelhetô meg a hetvenes évek elején, mely mind a kapcsolódó cikkek számának növekedésével, mind pedig a szakszerú és szisztematikus vizsgálatok megjelenésével jár. A legelsô cikk, melynek címében a „voluntary childlessness” kifejezés megjelenik, Kiser 1939-es tanulmánya. Ennél is korábbra tehetô azonban az elsô, az önkéntes gyermektelenséget a gyermekvállalási attitűdökkel és fertilitási mintázatokkal kapcsolatosan tárgyaló írások megjelenése. 1936-ban jelent meg Popenoe gyermekvállalási motivációkat vizsgáló tanulmánya és még hamarabb, 1924-ben Reynolds és Macomber a sterilitás relativitásáról és arról írnak, hogy az önkéntes és önkéntelen gyermektelenség között nem lehet mindig egyértelmú határokat vonni. A kifejezés korai megjelenéseit követôen kevés kivételtôl eltekintve (Popenoe, 1943) legközelebb a hatvanas-hetvenes évek kutatásai reflektálnak ismét a jelenségre. A téma társadalomtudományi alapjai is ekkor kerültek lefektetésre. Veevers (1972, 1973, 1974, 1975) és Houseknecht $(1977,1979,1987)$ fogalmai a mai napig meghatározó fontosságúak az önkéntes gyermektelenség irodalmának szempontjából. Az időbeli eloszlás vizsgálatának tekintetében a Web of Science vonatkozó indexe biztosíthat egyfajta kiindulási alapot (2018). Az elsôdleges kulcsszó itt összesen 154 találatot hoz, melyek 1971 és 2018 között kerültek publikálásra. Hasonlóan a vizsgálat alapjául szolgáló többi adatbázishoz, itt is legnagyobb arányban cikkek kerültek listázásra, melyek megjelenési gyakorisága az utóbbi két évtizedben megnốtt (1. ábra).

\section{ÁLTALÁNOS INFORMÁCIÓK}

\section{Fogalmi alapok}

Az önkéntes gyermektelenség vizsgálatához elengedhetetlenül fontosnak tûnik a jelenség minél pontosabb körülírása. Mindenekelốtt megemlítendô, hogy önmagában a gyermektelen jelzó nagyon tág definícióját adja egy olyan komplex jelenségkörnek, amelybe az önkéntes gyermektelenség is tartozik. Dariotis (2004) véleménye szerint az elóbbi, meglehetôsen tág fogalom azért sem alkalmazható ebben a specifikus esetben, 


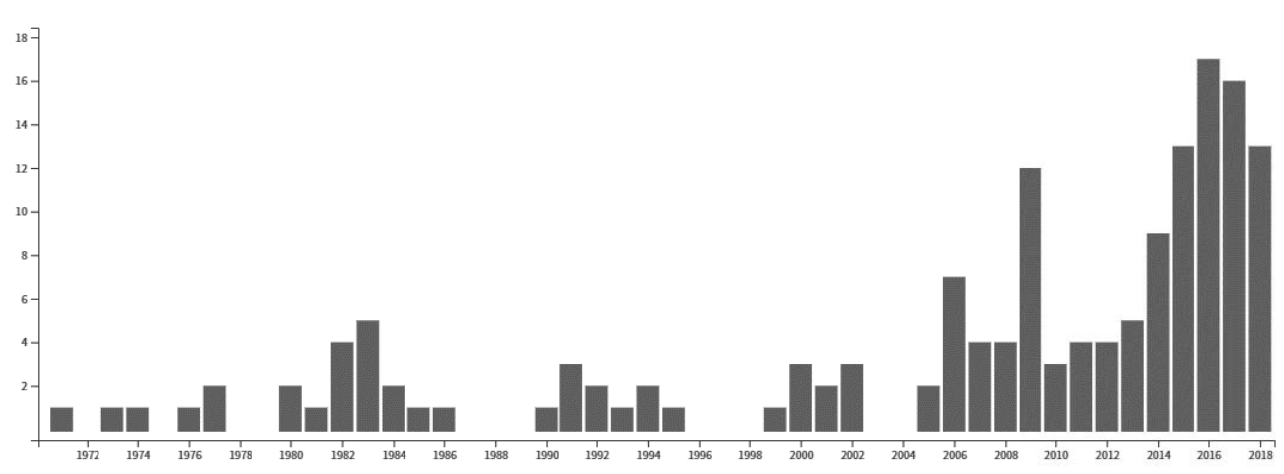

1. ábra. 1971 és 2018 között megjelent cikkek idôbeli eloszlása (Web of Science, 2018)

mert nem tesz különbséget a gyermekvállalástól tudatosan és akaratlagosan elzárkózók, illetve az összes többi, gyermeket az adott vizsgálat idôpontjában nem nevelôk csoportjai között. Két dimenziót emel ki a fogalmi precizitás elérésének alapjaként: a döntés véglegességét és szabadságát. Ezek azok a tényezôk, melyek elkülönítik az önkéntesen gyermekteleneket a döntésükben bizonytalanoktól, a meddôktôl és halogatóktól (Houseknecht, 1987).

Maga a megnevezés (voluntary childlessness, childless by choice, intentionally childless) a magyar nyelvú forsításokban önkéntes, akaratlagos vagy szándékolt gyermektelenségként jelenik meg elsôsorban. Az angol nyelvú szakirodalomban azonban az anyasággal szembeállított deficitet jelző szavak, mint a „gyermektelen” (childless) helyett a választás szabadságát hangsúlyozó egyéb megnevezések is elterjedtek, például a „gyermekmentes" (childfree) (Else-Quest és Hyde, 2013).

A szakirodalomban több definíció is megjelenik, ám jelen írás szempontjából a legtágabb leírás tekinthetô megfelelố kiindulási alapnak. Ez alapján önkéntesen gyermektelennek tekinthetố az a nô, aki (1) termékeny, szülooképes korú, de nem akar gyermeket, (2) aki szülóképes korú, de a sterilizáció mellett döntött, illetve (3) aki már nem szülőképes korú, de korábbi termékenysége ellenére úgy döntött, hogy nem szül gyermeket (Kelly, 2009).

Jelen definíció közlése mellett fontos megjegyezni, hogy sok kutató tartja nehezen leírhatónak az önkéntes gyermektelenség fogalmát, két okból kifolyólag. Egyrészt megkérdôjelezhetônek tartják a választás szabadságát - könnyen belátható, hogy a retrospektív önbeszámolók vagy akár a jelenre vonatkozó elmondások torzíthatják a valóságot, ezzel nehezítve a konzekvens feltárási folyamatokat. Ilyen szempontból tehát megkérdôjelezhetô, hogy valóban önkéntes választásról van-e szó, vagy a gyermekvállalásról való lemondás legitimizációjáról, netán akaratlagos és akaratlanul bekövetkezô tényezôk kombinációjáról (Doyle, Pooley és Breen, 2013). Néhány tanulmány éppen ezért inkább a „választásból fakadóan gyermektelen” (childless by choice) és a „körülményekbôl fakadóan gyermektelen” (childless by circumstance) fogalmi szétválasztást részesíti elônyben (Cannold, 2004).

Másrészt problematikusnak tekinthetố a lezáratlanság problémája a fentebb használt definíció elsố kategóriájában. Eszerint ugyanis a szülốképes korú nôk (15-49 év) 
gyermekvállalásra való hajlandósága az idô folyamán változhat, következésképpen nem sorolhatóak egy csoportba a már lezárt termékenységi idô miatt valóban gyermektelenül maradó társaikkal azok, akik még nem érték el ezt a kort (Szalma és Takács, 2012).

Külön problémát jelenthet a gyermekvállalásról többszöri halogatás után, kényszerbốl lemondó nôk kategorizációja: kérdéses, hogy ôk az önkéntesen gyermektelen kategória tagjaihoz tartoznak-e inkább, vagy azok közé, akik bizonyos külsô tényezôk okán nem vállalnak gyermeket (Szalma és Takács, 2012). Ezt a dilemmát valamelyest árnyalhatja, egyszersmind segíthet a fogalmi háttér tisztázásában a különbözó életutat bejáró önkéntesen gyermektelenek e szempontból történô csoportosítása során kialakított meghatározások feltárása.

Két jelentôs megközelítés létezik a témában, az elsô szerint az önkéntesen gyermektelenek két kategóriába oszthatóak; léteznek „korai kinyilvánítók” (early articulators) és „halogatók” (postponers). A korai kinyilvánítók aránylag korán döntenek gyermektelenségük mellett, míg a halogatók jellemzóen több alkalommal elhalasztják a végsố döntést, és viszonylag késôn jutnak erre az álláspontra. Arányaikat tekintve a halogatók csoportja nagyobb: az önkéntesen gyermektelen nôk kétharmadát teszik ki (Houseknecht, 1979).

Houseknecht két kategóriáját vitatva Dariotis hármas felosztás mellett érvelt, szerinte ugyanis a halogatók alcsoportjai nem tisztázottak a fentebb leírt kettôs csoportosítás alapján (Dariotis, 2004). Az ô három kategóriája a „korai kinyilvánítók” (early articulators), a „kései kinyilvánítók” (late articulators), valamint a „folytonos halogatók” (perpetual postponers) csoportjaiból állt. Ez utóbbi két csoportot a halogatók két alcsoportjából hozta létre: kései kinyilvánítók azok, akik a döntést életük egy késôbbi pontján hozzák meg, míg a folytonos halogatók élete passzív döntések sorozatából áll.

Újabb megnevezést vezetett be Lunneborg (1999), aki a „beleegyezók” (acquiescers) névvel azokat az önkéntesen gyermektelen felnôtteket illette, akik semlegesebben viseltetnek a gyermekvállalás témájával kapcsolatban, nézeteiket és preferenciájukat partnerükéhez igazítják. A kategóriába meglátása szerint leginkább férfiak tartoznak.

\section{Eltérô életutak}

Az imént tisztázott, fejlôdéslélektani sajátosságaik mentén különálló csoportokba osztható önkéntes gyermektelenek kapcsán Dariotis (2004) pontosabb pszichológiai megközelítésre is törekedett. Vizsgálata során sorra vette a fentebb ismertetett csoportokat lélektani jellegzetességeik mentén:

1. Korai kinyilvánítók: A korai kinyilvánítók leginkább személyes preferenciáik és attitúdjeik, valamint családjukban tapasztalt problémáik alapján hozzák meg gyermekvállalással kapcsolatos döntésüket, méghozzá tizenéves korukban vagy húszas éveik elején. Gyakran állhat a háttérben korábban, kényszerbôl felvett szülői szerep (fiatalabb testvéreikre való felvigyázás), a szülői szereppel való azonosulás nehézségei, karrierpreferenciák, traumatikus családi emlékek, illetve a gyermek-szülô kapcsolati dinamika negatív munkamodellje. Mindezek okán ezen csoport tagjai változtatják meg véleményüket a legkisebb valószínúséggel - nem csupán a fenti, nehezen megváltoztatható benyomások játszanak ebben közre, hanem az ezekból gyakran követ- 
kezô házassági preferenciák (a partner gyermekvállalási vágyai hasonlóak, a házasság akaratlagos kerülése vagy a lehetséges partnerek elutasítása) is.

2. Kései kinyilvánítók: A kései kinyilvánítók ezzel szemben húszas éveikben, netán harmincas éveik elején jutnak döntésre, melyet karrier- és életviteli preferenciákkal indokolnak. Általában jellemzô rájuk, hogy a gyermekvállalás és életük egyéb, szubjektíve fontosabb területei (párkapcsolat, karrier, szabadság) nem túnnek összeegyeztethetônek számukra. Kiegészíthetik ezeket az elképzeléseket az eddigre megszerzett, gyermekekkel kapcsolatos tapasztalatok, testi és mentális betegségek és partnerük kilétének ismerete is.

3. Folytonos halogatók: A folytonos halogatók döntése a legkevésbé egyértelmú és végleges. Esetükben leginkább egyfajta passzív döntéshozatalról beszélhetünk, mely döntések láncolatából áll. Ezen döntések hátterében tipikusan a gyermekvállalás idôzítésének nehézsége áll, az az érzés, hogy az idô éppen akkor nem alkalmas valamilyen tanulmányokkal, karrierrel vagy párkapcsolati státusszal kapcsolatos okból kifolyólag. Számukra a folyamat lezárását negyvenes éveik jelentik, amikorra már biológiai nehézségekbe ütközne a gyermekvállalás.

Avison és Furnham 2013-as vizsgálata során a gyermekre nem vágyók csoportjának 59\%-a bizonyult korai kinyilvánítónak, vagyis ennyien gondolták úgy, hogy már serdülőkorukban vagy akár korábban tudták, hogy nem akarnak gyermeket vállalni. A vizsgálat tanulsága szerint a korai kinyilvánítók szignifikánsan magasabb nyitottságés önállóságértékekkel rendelkeznek az önkéntesen gyermektelen csoport többi tagjához képest. Valószínúbben támogatnak környezettel, élővilággal és kultúrával kapcsolatos ügyeket és kevésbé valószínú, hogy ifjúságvédelmi szervezeteket támogatnak. A vizsgálat azonban nem tárt fel különbségeket születési sorrend, testvérszám, vallásosság, politikai orientáció és háziállatokkal kapcsolatos preferenciák terén.

\section{Önkéntes gyermektelenség nemzetközi viszonylatban}

Globális szinten elmondható, hogy míg a legtöbb fejlett országban visszaestek a termékenységi számok, és a reprodukciót lehetôvé tévố 2,1-es számot csak kevés ország mutatói haladják meg, addig a fejlôdő országokban sokszor fordított a helyzet. Bár az eredmények gyakran ellentmondásosak, egyes vizsgálatok szerint a világ egyetlen részén sem valószínú, hogy az önkéntes gyermektelenség legyen a meghatározó tendencia akár csak egyetlen homogén társadalmi csoport esetében is (Basu, 2002).

Az 1960-as évek óta az USA-ban is megnövekedett a gyermektelenek aránya, és ezzel együtt nốtt az önkéntesen gyermektelenek száma is. Az utóbbi években azonban ez a növekedés megállt és ellenkezôjére fordult; a Pew Research Center (2015) adatai szerint 2014-ben a 40 és 44 év közötti nôk 15\%-ának nem volt gyermeke. Ez ugyan visszaesés a pár évvel korábbi 20\%-os arányhoz képest, de még mindig 50\%-os növekedésnek számít az 1976-os szinthez képest (2. ábra).

Önmagában ez az adat nem árulkodik azonban a gyermekvállalásról önként lemondók számáról. Abma és Martinez (2006) vizsgálatuk során azt találták, hogy a gyermektelen, 35 és 44 év közötti nôk 42\%-a önkéntesen gyermektelennek vallotta magát, 30\% ítélte idólegesnek ezt az állapotot, a fennmaradó $28 \%$ pedig önkéntelenül maradt 


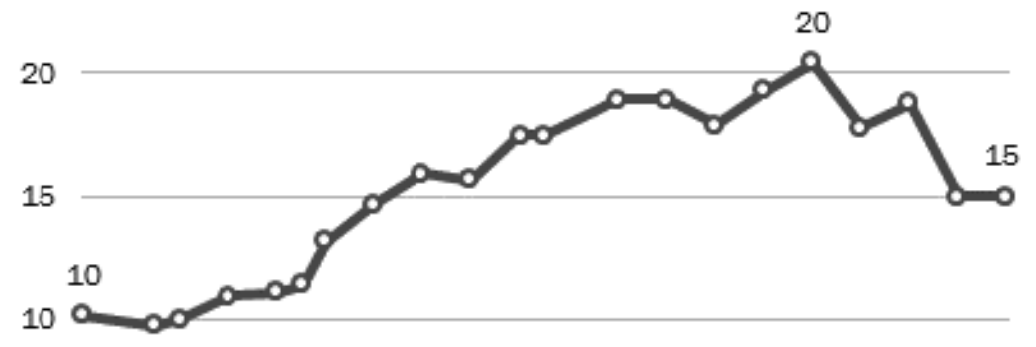

5

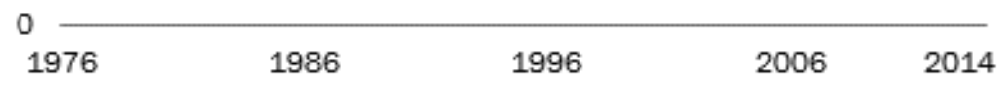

2. ábra. Önkéntesen gyermektelenek aránya a 40-44 év közötti nôk körében (Pew Research Center, 2015)

gyermektelen. Tágabb korosztályt vizsgálva, a 15-44 éves amerikai nôk 61,8 millió fôs populációján belül 2006 és 2010 között 43\% volt gyermektelen, és ebból 6\% vallotta magát önkéntesen gyermektelennek (Martinez, Daniels és Chandra, 2012).

Az amerikai adatokhoz hasonló számok jelennek meg az európai szakirodalomban is. Az 1968-as születésú nôk közül a gyermektelenül maradók arányát tekintve az európai átlag 14\%, mely országtól függóen 8-25\% között mozog (Beaujouan, Sobotka, Brzozowska és Zeman, 2017). A gyermekre nem vágyó 18-40 éves felnốttek aránya a vizsgált európai országokban 1-16\% között mozgott - a vizsgálat eredményei alapján a legalacsonyabb aránnyal a kelet-európai országok, valamint Franciaország, Írország és Portugália, a legmagasabbal pedig Hollandia rendelkezett (Miettinen és Szalma, 2014).

Az Európában és az USA-ban megfigyelhetô születésszámban bekövetkezett csökkenés jellemzi Japán társadalmát is (Ashbrun-Nardo, 2016). Ami a fejlődő országokat illeti, a legtöbb kevéssé fejlett társadalomban a negyvenes éveik végére gyermektelenül maradó nôk aránya nem haladja meg a 10\%-ot, egyes országokban (India, Törökország, Pakisztán, Dél-Afrika) pedig az 5\%-ot sem (Chamie és Mirkin, 2012; Masebe és Ramosebudi, 2015). Ezekben az országokban azonban gyakran nem érhetôek el az önkéntes gyermektelenségre vonatkozó adatok.

\section{Önkéntes gyermektelenség Magyarországon}

Ami a jelenség hazai sajátosságait illeti, az utóbbi években megjelent néhány kutatás segítségével a legfontosabb tudnivalók adottak. A magyar társadalom a kiemelten gyermekcentrikus társadalmak közé sorolható gyermekvállalással kapcsolatos preferenciái 
2. táblázat. Mennyire jó, ha egy házaspárnak X számú gyermeke van? 18-50 év közötti férfiak és nók véleménye, 1988, 1997, 2009, \% (S. Molnár, 2009, 290)

\begin{tabular}{l|c|c|c|c|c}
\hline $\begin{array}{l}\text { Ha egy házaspárnak } \\
\text { nincs gyermeke }\end{array}$ & $\begin{array}{c}\text { Nagyon jó } \\
\text { vagy jó }\end{array}$ & $\begin{array}{c}\text { Sem nem jó, sem } \\
\text { nem rossz }\end{array}$ & $\begin{array}{c}\text { Rossz vagy na- } \\
\text { gyon rossz }\end{array}$ & $\begin{array}{c}\text { Egyéb véle- } \\
\text { mény vagy } \\
\text { nem tudja }\end{array}$ & Összesen \\
\hline 1988 & 1,2 & 22,3 & 75,8 & 0,6 & 100,0 \\
\hline 1997 & 3,8 & 16,3 & 75,8 & 4,0 & 100,0 \\
\hline 2009 & 6,3 & 17,8 & 73,8 & 2,1 & 100,0 \\
\hline
\end{tabular}

alapján, a csökkenô populációs szám ellenére is. Ezek kettôsének következtében az (önkéntes) gyermektelenség témaköre igen érzékeny és nagyon vitatott kérdéskörnek számít (Szalma és Takács, 2016).

A közvéleményben és a magyar kutatási anyagokban egyaránt megjelenô ideális nô képének fontos része az anyai szerep, s a közhiedelmek szerint a gyermekek jelenléte a családban az élet elengedhetetlen része (Szalma, 2010). A gyermektelenség növekvô arányát a magyar megkérdezettek legnagyobb része $(84,9 \%)$ negatív tendenciának értékeli (Pongrácz, 2007), és mértékében jelentôsen túlbecsüli a valós adatokhoz képest (Szalma és Takács, 2016). Ugyanakkor egy másik kutatás eredményei szerint ez a tendencia mutat némi változást az utóbbi néhány évtizedben (lásd a 2. táblázatot); míg 1988-ban a megkérdezettek 1,2\%-a tartotta jónak, ha egy házaspárnak nincs gyermeke, addig 2009-ben ez az arány már 6,3\% volt (S. Molnár, 2009).

Ami az önkéntesen gyermektelen életmód mellett határozók valós arányát illeti, a fenti fogalmi nehézségek mentén a magyar kutatók igen nagy különbségeket mutatnak megközelítésük és eredményeik alapján. Míg Tarkányi a GfK Roper által közreadott jelentést idézve 20\%-os arányról ír a 13-19 éves lányok körében (GfK Roper, 2008), addig más kutatók arról írnak, hogy Magyarországon ez az arány a 18-40 éves nôk körében stabilan 2\% alattira tehetô (Szalma és Takács, 2016).

Szokatlannak tûnhet az imént bemutatott, 13-19 évesek esetében publikált adatok ismertetése, hiszen megkérdőjelezhetô ezen jövôbeli elképzelések stabilitása. Szem elốtt tartva, hogy kiskorúakról van szó, belátható, hogy az adatok interpretálása önmagában nehézkes. Érdemes azonban azt is figyelembe venni, hogy a fiatalok egy része a fentebb már ismertetett korai kinyilvánítók közé is tartozhat. Ezen csoport korai attitûdjei pedig igen stabilnak bizonyulnak, ôk változtatják meg véleményüket a legkisebb valószínúséggel, és sok esetben ezt a véleményt már tizenévesen következetesen képviselik (Dariotis, 2004).

Igaz azonban az, hogy Nyugat-Európában és Észak-Amerikában egyre több nô választja a gyermektelen életformát (Gillespie, 2003). Emellett Magyarországon a gyermektelen 41-45 éves nók aránya az utóbbi évtizedben jelentôs növekedést mutatott; míg 2001-ben 7,8\% volt, 2011-ben már 11,2\%-ra emelkedett (Szabó, 2015). Vitatható azonban, hogy ez a jelenség milyen mértékben függ össze eredeti elhatározásukkal és az általuk kívánt gyermekszámmal, vagyis mennyien tekinthetôek ezen nôk közül önkéntesen gyermektelennek. 


\section{Szociáldemográfiai sajátosságok}

A gyermekszám szempontjából leginkább meghatározó szociáldemográfiai jellemzô nôk esetében a végzettség, mely fordított korrelációt mutat a gyermekvállalási motivációval és a gyermekszámmal is (Abma és Martinez, 2006). Más szerzôk azonban a végzettség fokánál fontosabb tényezônek tartják annak irányát. Az egészségügyi és pedagógiai pályát választó nôk között szignifikánsan kevesebb a gyermektelen, mint humántudományokat és múvészeteket preferáló társaik esetén, ráadásul az elóbbi csoport termékenységi rátája is magasabb az utóbbiénál (Hoem, Neyer és Andersson, 2006; Masebe és Ramosebudi, 2015).

Elmondható ugyanakkor az is, hogy noha még mindig nagy különbségek vannak végzettség szerint a gyermektelenek arányában, ez a különbség az utóbbi idôben csökkenni látszott. A Pew Research Center 2015-ös összehasonlító vizsgálata alapján érzékelhetố tendencia, hogy a gyermektelenül maradók aránya minden múveltségi csoportban visszaesett, de különösen nagy ez a különbség a magasabb végzettségú csoportokban. Elemzésük szerint ennek oka lehet egyrészt az, hogy egyre többen, többféle társadalmi csoportból szereznek magasabb végzettséget a korábbi tendenciákhoz képest. Fontos tényezô lehet az is, hogy a technológiai fejlődés egyre inkább lehetôvé teszi a gyermekvállalás halasztását, így a felsôoktatásban több idôt eltöltôknek is van lehetôsége késôbb szülôvé válni.

A 3. ábra ezen kutatás eredményeinek egy részét hivatott bemutatni - leolvasható belôle a 40 és 44 éves életkor közötti, gyermektelen nôk végzettség szerinti, százalékban kifejezett arányának 1994 és 2014 közti változása. A feltüntetett százalékos arányszámok kapcsán fontos megjegyezni, hogy nem egy-egy év értékeit veszik csupán alapul, vagyis az 1994 jelzés valójában három különböző évben gyújtött adatok (1992, 1994 és 1995), míg a 2014 jelzés két különbözô év adatainak (2012, 2014) kombinációján alapszik. Ugyan az ehhez hasonló kombinált értékek alapjában véve nehezítik az adatsorok értelmezhetôségét, a tanulmány szerzôi mégis ezen eljárás mellett döntöttek a megfelelô méretû minta kialakításának céljából. Ahogy az több, a jelen írás során is ismertetett kutatás kapcsán is elmondható, úgy ebben az esetben kiemelten igaz az, hogy a téma szempontjából releváns kutatások és adatok hiánya nagyban nehezíti annak elemezhetôségét és konzekvens vizsgálatát.

Foglalkoztatottság és kereset tekintetében is mutatkoznak különbségek, ugyanis az önkéntesen gyermektelen nôk bírtak a legmagasabb keresettel és legtöbb elôzetes munkatapasztalattal gyermeket vállalni vágyó vagy akaratuk ellenére gyermektelen társaikhoz képest. Emellett nagyobb valószínúséggel töltenek be vezetôi pozíciókat és élnek városokban (Abma és Martinez, 2006), illetve nagyobb valószínúséggel végeznek teljes munkaidős munkát (Avison és Furnham, 2015).

A gyermekmentes személyek sajátosságait taglaló szakirodalmi források jelentôs része nôkre irányul, de ma már elérhetôek az önkéntesen gyermektelen férfiakra vonatkozó adatok is. Waren és Pals (2013) eredményei alapján elmondható, hogy nagyon hasonló demográfiai és szocializációs sajátosságokkal bírnak a gyermekmentes nôk és férfiak egyaránt. Emellett mindkét nem esetén a hagyományos nemi szerepekbe vetett hit mértékével csökken a gyermekmentes életforma valószínúsége - ez a tényezó valamivel erôteljesebb bejóslója a nôk ilyen irányú döntésének. Ezzel szemben az isko- 


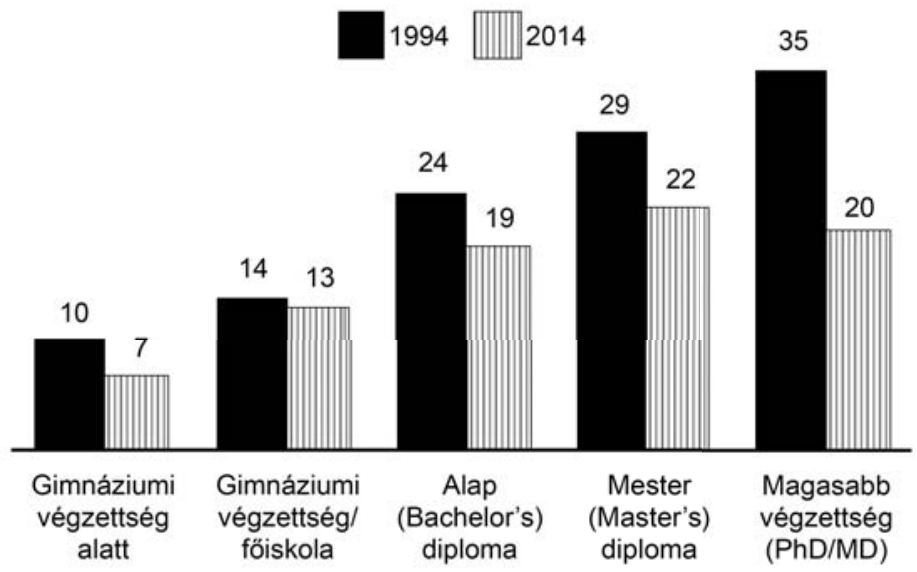

3. ábra. 40-44 év közti gyermektelen nôk végzettség szerinti aránya (Pew Research Center, 2015)

lai végzettség kapcsán mutatkoznak szignifikáns különbségek a két nem tekintetében - míg a nôk magasabb iskolai végzettség esetén nagyobb valószínúséggel választják a gyermekmentes életformát, addig a férfiak tekintetében nem tekinthetô a gyermekmentes életforma szignifikáns elôrejelzőjének az iskolai végzettségük foka.

Vallásosság szempontjából szignifikánsan különböznek az önkéntesen gyermektelenek Avison és Furnham (2013) kutatása alapján. A gyermekre vágyókkal szemben lényegesen kevésbé valószínú, hogy vallásosnak tartják magukat - a megkérdezettek 48\%-a nem tartotta magát vallásosnak, míg a gyermekre vágyók csoportja 23\%-os arányban vetette el a vallásosság gondolatát. A vágyott gyermekek ideális száma, valamint a szülôvé válásra való vágy mértéke is pozitív korrelációt mutatott a vallásosság mértékével.

Politikai beállítottság tekintetében elmondható, hogy az önkéntesen gyermektelenek inkább liberális eszméket vallanak, és szignifikánsan magasabb átlagértékekkel rendelkeznek liberális kérdésekkel való egyetértés terén, mint a gyermeket vállalni vágyók csoportja (Avison és Furnham, 2013). Kevésbé konzervatívak, és nagyobb esélylyel vallanak hagyományostól eltérô elképzeléseket, többek között a nemi egyenlôség tekintetében is (Abma és Martinez, 2006; Waren és Pals, 2013).

Ugyanezen kutatás során Avison és Furnham (2013) arra az eredményre jutottak, hogy a gyermekre nem vágyók szignifikánsan nagyobb arányban tartanak háziállatokat, s ami az állatok fajtáját illeti, preferenciájuk megegyezik a gyermekre vágyókéval. Szintén ebbôl a vizsgálatból következô eredmény, hogy az önkéntesen gyermektelenek szignifikánsan nagyobb arányban támogatnak adományokkal különbözô jótékonysági szervezeteket. A vizsgálat során a támogatott ügyek típusai között is találtak különbségeket (lásd a 4. ábrát); a gyermekre nem vágyók szignifikánsan valószínúbben támogattak természettel és kultúrával kapcsolatos ügyeket, míg a gyermekre vágyók csoportja inkább az egészséggel, gyermekekkel, nemzetközi fejlôdéssel és hajléktalansággal kapcsolatos kérdéseket preferálta. 


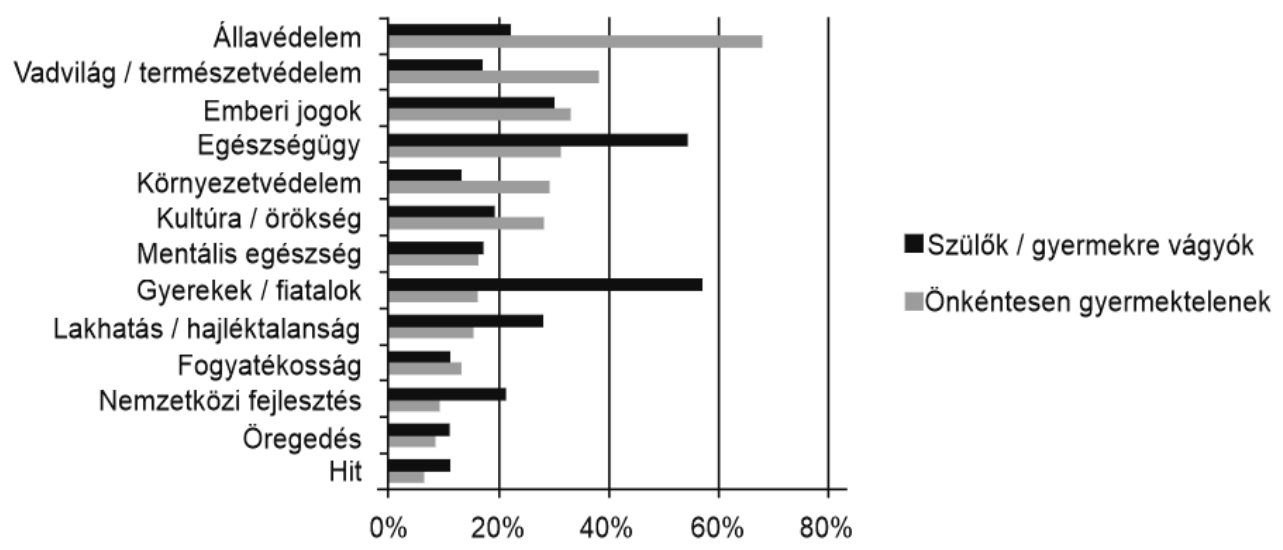

4. ábra. Jótékonysági ügyek támogatottságuk mértéke szerint (Avison és Furnham, 2013)

Összességében elmondható tehát, hogy a gyermekmentes életformát választó nôk tipikusan magasan iskolázottak, karrier- és célorientáltak, teljes munkaidôben dolgoznak, nem élnek házasságban, nem vallásosak. Fizetésük magasabb, mint gyermeket vállalni vágyó társaiké, és hozzájuk képest kevésbé konzervatívak (Bays, 2016). Az önkéntesen gyermektelen férfiak sok tekintetben a gyermekmentes nôkhöz hasonló szocializációs és demográfiai háttérrel rendelkeznek, de esetükben iskolai végzettségük foka nem függ össze gyermekvállalási hajlandóságukkal.

\section{PSZICHOLÓGIAI SAJÁTOSSÁGOK: SZEMÉLYISÉGJELLEMZÔKK}

A téma szakmai vizsgálatának szempontjából nehezítô tényezô, hogy az önkéntesen gyermektelen nôk csoportja nem alkot homogén csoportot (Szalma és Takács, 2016). Tagjai nem ugyanazon okokból kifolyólag jutnak el döntésükhöz, fejlődési folyamataik eltéréseket mutatnak, nemi és szexuális orientációjuk széles skálán mozoghat, koruk, vallási beállítódásuk és motivációik változatosak lehetnek, ahogy kapcsolati státuszukban is mutatkoznak eltérések, melyek hatással vannak társadalmi megítélésükre is. Ezen sajátosságok ismerete meghatározó fontosságú a téma vizsgálatához. Ennek ellenére is beszélhetünk olyan pszichológiai meghatározókról, melyek specifikusak ezen heterogén csoport tagjaira.

Számos személyiséglélektani kutatás foglalkozik a gyermekvállalás témaköréhez ilyen vagy olyan módon kapcsolódó jelenségek feltárásával. Ilyen jelenségek például a szexuális viselkedés, a házasság vagy akár a romantikus kapcsolatok témaköre (Miller, 1992; Jokela, Kivimäki, Elovainio és Keltikangas-Järvinen, 2009). Belátható tehát, hogy a téma szempontjából fontos vizsgálni azt is, hogy a személyiség milyen kapcsolatban állhat a gyermekvállalásra való hajlandósággal, illetve - ebben az adott esetben - annak hiányával. 


\section{Az önkéntesen gyermektelenek személyisége}

Ami az önkéntesen gyermektelen nôk személyiséglélektani sajátosságait illeti, több kutatás (Houseknecht, 1979; Miller, 1992; Avison és Furnham, 2015) eredményei alapján megállapítható, hogy az önkéntesen gyermektelenek magasabb autonómiaigénnyel és magasabb teljesítménymotivációval rendelkeznek gyermeket vállalni vágyó társaiknál. E két tulajdonság és a gyermektelen életmód preferenciájának együttes megléte esetén pedig megnövekszik a valószínúsége annak, hogy e mellett az életmód mellett döntenek.

Személyiséglélektani sajátosságaik vizsgálatához Avison és Furnham (2015) a Big Five személyiségvizsgáló kérdőívet és kiegészítô módszereket használta. Kutatásuk során azt találták, hogy az önkéntesen gyermektelen nók három faktor mentén is szignifikáns eltérést mutatnak gyermeket vállalni vágyó társaikhoz képest. Eredményeik alapján megállapítható, hogy az előbbi csoport mind barátságosság, mind pedig extraverzió tekintetében alacsonyabb, míg önállóság tekintetében magasabb átlag pontértékekkel rendelkezik, mint a gyermeket vállalni vágyó nôk csoportja. Neuroticizmus- és nyitottságértékeik is magasabbnak bizonyultak a másik csoporténál, ám ez a különbség nem volt szignifikáns.

Ugyanezen vizsgálat során állapították meg azt is, hogy a barátságosság értékkel nô a gyermekvállalási vágy értéke, míg az önállóság értékének növekedésével ez csökken. A barátságosság volt továbbá az egyetlen faktor, amely összefüggésbe hozható volt a gyermekek számának kívánt értékével; a magasabb értékkel rendelkezôk több gyermekre vágytak. Ezen eredmény alapján feltételezhetô, hogy ez a jellemzó fontos szerepet tölt be a gyermekvállalási motiváció alakulásában. Nyitottság szempontjából ugyan nem találtak szignifikáns különbségeket a fenti két csoport között, de érdekes megállapításra jutottak a gyermektelen csoport alcsoportjai kapcsán. Vonatkozó összehasonlításaik során azt találták, hogy azok, akik aránylag korán eldöntik, hogy gyermektelenek akarnak lenni, szignifikánsan nyitottabbaknak és önállóbbnak bizonyultak összes többi társuknál, de extraverzió és barátságosság terén nem mutattak eltérést.

A gyermektelenség mellett határozók és gyermekre vágyó társaik között intelligencia tekintetében is mutatkoznak különbségek. Kanazawa (2014) eredményei szerint mind férfiak, mind pedig nôk esetén a magasabb intelligencia nagyobb eséllyel jár együtt a gyermekmentes életút vágyával, de csak magas intelligenciájú nốk esetén válik valószínúbbé az, hogy valóban így határoznak. A gyermekkori intelligencia szintjének egy standard deviációval (15 IQ-pont) való növelése 21-25\%-os csökkenést eredményez az anyává válás valószínúségében. Ezen elôrejelzés alapján tehát a gyermekkorukban az átlagos intelligenciát 15 IQ-ponttal meghaladó intelligenciájú nôk 21-25\%-kal kisebb eséllyel válnak anyává, de 30 IQ-pontos eltérés esetén ez az arány akár 50\%-ra is módosulhat. A szerzó megállapítása szerint ez is hozzájárul az átlag intelligenciaszint csökkenéséhez a fejlett ipari társadalmakban.

Látható, hogy a fenti eredmények alapján valóban találhatóak személyiséglélektani különbségek gyermekre vágyó, illetve önkéntes gyermektelenség mellett döntô nôk esetén. Másfelől ez alapján feltételezhetô, hogy a Houseknecht (1979) által leírt csoportok, vagyis a gyermektelenségre vonatkozó döntésüket korán meghozók és a döntést halogatók közötti különbségek személyiséglélektani jelleggel is jelentkeznek. 


\section{Személyiségjellemzók genetikai meghatározottsága}

A gyermekvállalásra vagy annak elkerülésére motiváló tényezôk vizsgálata tehát elengedhetetlen a téma szempontjából. Mindenekelôtt érdemes szót ejteni a biológiai determináció kérdéskörérôl, vagyis arról, hogy a gyermekvállalást meghatározó személyiségjellemzôk és személyes motívumok vajon milyen mértékben függnek örökletes hatásoktól. Egyes korai kutatások azt látszanak igazolni, hogy személyiségjegyeink 30-50\%-a genetikailag determinált (Bouchard, Lykken, McGue, Segal és Tellegen, 1990; Plomin, 1990), mások a jelen témához közvetlenül kötôdô fertilitási vágy és szándék, illetve a gondoskodási motiváció örökletességével kapcsolatban végeztek kutatásokat (McAllister, Pepper, Virgo és Coall, 2016).

Miller (2011) egyike volt ezeknek a kutatóknak. Kapcsolódó felvetése szerint létezhetnek olyan örökletes genetikai tényezôk, melyek (részben) felelôssé tehetôek a gyermekvállalással kapcsolatos attitúdökért és a magas fertilitásért. Kutatásai során talált olyan örökletességi faktort, mely az általa két komponensre bontott fertilitással kapcsolatos viselkedés jelentôs részét magyarázhatja. Megfogalmazásában ez a két komponens - a fertilitási vágy és a fertilitási szándék - jól elkülöníthetôek, a vágyak egy, a gyermekvállaláshoz vezetô szekvenciális folyamatban megelôzik a szándékokat. Feltételezései szerint a fertilitási vágyak 70\%-áért, míg a fertilitási szándékok 40\%-áért ez az örökletes faktor tehetô felelôssé. Leírásában három genetikai polimorfizmusra hívta fel a figyelmet (CNR1 kannabinoid receptor, OXTR oxitocin receptor és HTT szerotonin transzporter). Ezek szoros kapcsolatban állhatnak olyan személyiségjellemzókkel, melyek nagyban meghatározhatják a termékenységgel kapcsolatos motivációk, vágyak és szándékok alakulását. Alábbi sematikus modelljében (5. ábra), melynek alapját korábbi kutatásai adják, ezt a jelenséget kívánta szemléltetni.

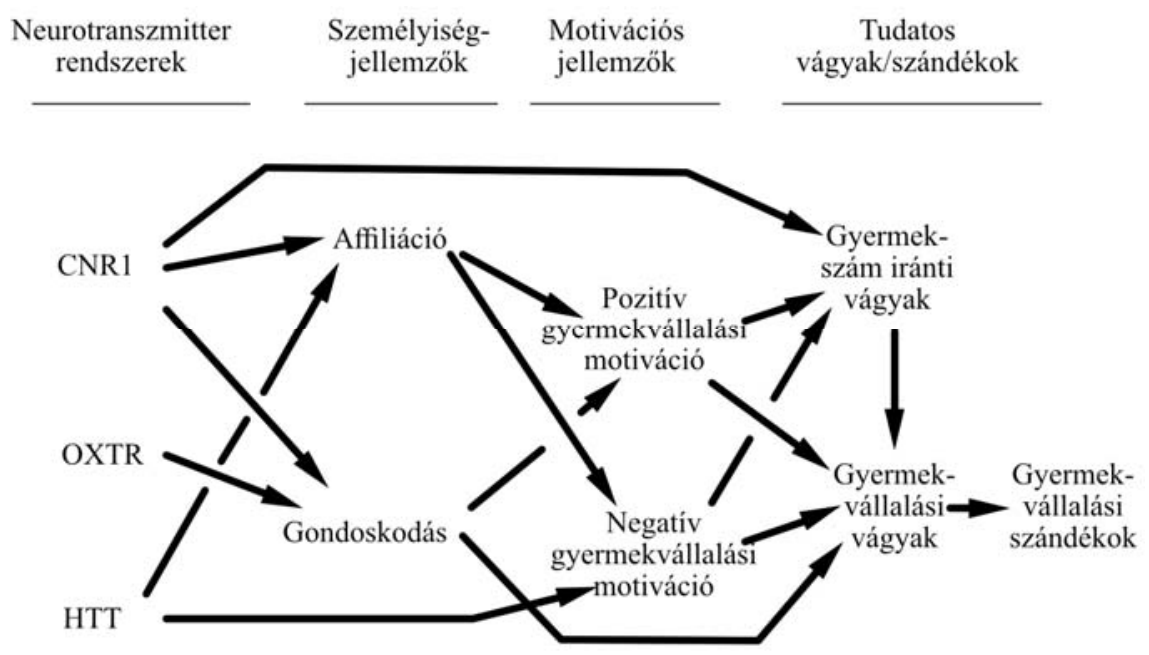

5. ábra. A három genetikai polimorfizmust a személyiségjellemzókhöz és motivációs komponensekhez kötố modell sematikus reprezentációja (Miller, 2011, 84) 
Szintén a gondoskodási vágyra mint a gyermekvállalást meghatározó személyiségjellemzôre reflektál Basten (2009), aki evolúciós pszichológiai megközelítésben értekezik a kérdésrôl. Szerinte ez a jellemzô a párválasztási szelekció során emelkedhetett ki, hiszen megléte egyfajta elôzetes bizonyítéka lehet a szüloói képességeknek. Feltételezhetô, hogy hormonálisan meghatározott és kontrollált tulajdonságról van szó, melynek erôsségét több tényezô is befolyásolhatja, így például egy elkötelezett párkapcsolat megléte, a háztartási szerepek rendszere vagy az életkor. A kapcsolódó gyermekkori tapasztalatok is meghatározó fontosságúak lehetnek alakulásában, így például a fiatalabb testvérekre való vigyázás is korai kulcsává válhat e tulajdonság kibontakozásának. Mértéke késôbb is növekedhet a felnôttkori tapasztalatok, például gyermekekkel való interakció hatására.

E témakör bôvebb és pontosabb kifejtése önmagában is jócskán meghaladja jelen írás terjedelmi és tartalmi korlátait, jelentôsége miatt viszont mindenképpen helye van az önkéntes gyermektelenség pszichológiáját feltáró kutatási anyagban. A leírtak mellett igaz azonban az is, hogy a genetikai tényezók pontos hatásmechanizmusának tekintetében a mai napig megoszlanak a vélemények. Egyesek szerint a gyermekvállalási motiváció kizárólagos genetikai meghatározottsága nemcsak nem egyértelmú, de igen valószínútlen is. Basten (2009) összefoglaló elemzésében megjegyzi, hogy számos szerzó álláspontja szerint ahelyett, hogy kizárólagosan örökletes hatásokat keresnénk, érdemesebb lehet egymással interakcióba kerülô tényezók egész spektrumát feltárni. Ezek a hatások ugyanis felróhatóak megannyi hatásnak, így például a kulturális hagyatéknak, genetikának, tapasztalatoknak és környezeti hatásoknak is. Az ok-okozati kapcsolatok feltárásának nehézsége miatt a McAllister és munkatársai által összeállított metaanalízis konklúziójában is arra utalnak, hogy több kutatásra és újragondolt módszertani megközelítésre lesz szükség a korrelációs eredmények kauzális útvonallá rendezésének érdekében (McAllister, Pepper, Virgo és Coall, 2016).

\section{A gyeremekmentesség motivációs összetevôi}

Motivációk tekintetében a legfontosabb tényezô a szabadság és autonómia keresése. A gyermekvállalással járó kötelezettségektôl való függetlenedés vágya és a szabadság magasra értékelése több kutatásban is a résztvevôk mintegy $80 \%$-a szerint volt fontos meghatározója döntésüknek (Avison és Furnham, 2015). A válaszok alapján úgy tûnik, hogy öt fố motivációs faktor különíthetô el, és ezek különböznek abban is, hogy mely személyiségjegyekkel mutatnak összefüggéseket.

Elkülönítésre kerültek egyrészt (1) olyan általánosan elfogadott nézetek, melyek nem korreláltak egyetlen személyiségjellemzôvel sem. Ezekkel a legtöbb válaszadó egyetértett és azonosulni tudott. Ilyenek voltak például a szabadságra és nyugalomra való vágy, illetve a felelôsség kerülésének vágya.

Megjelentek (2) intrinzik érvek, amelyeknek magas értékei együttjárást mutattak a függetlenség és neuroticizmus magas értékeivel, valamint az extraverzió és barátságosság alacsony mértékével. Ezek leginkább az anyai és szülooi ösztön hiányának érzéséhez kapcsolódtak, illetve megjelent köztük a gyerekek társaságának kerülésére való vágy. 
Újabb csoportot alkottak az (3) ideológiai aggodalmak, mint például a túlnépesedéstôl való félelem, az önbeteljesítésre való irányultság és a társadalmi közremúködés vágya. Azoknak a személyeknek, akiket ezek a kérdések kiemelten foglalkoztattak, nyitottságértékeik is magasak voltak.

A (4) gyermekvállalással kapcsolatos aggodalmak, így például a gyermeknevelési nehézségektôl való félelem, külön csoportba kerültek. Személyiségjegyek szempontjából elmondható, hogy az ezen motivációkat felsorakoztató személyek magasabb fokú neuroticizmussal és alacsonyabb értékú extraverzióval, függetlenséggel és lelkiismeretességgel voltak jellemezhetôek.

Végül a (5) kifejezetten nók számára releváns érvek alkották az utolsó kategóriát. Itt megjelentek a karrierrel, a gyermekgondozási kötelezettségek egyenlőtlen megosztásával és a testi következményekkel kapcsolatos félelmek, melyek a lelkiismeretesség-értékkel álltak pozitív korrelációban (Avison és Furnham, 2013).

Ezeken túl gyakran említett motívumok más kutatások alapján a spontán mobilitás korlátozásától való félelem, a más felnôttekkel (kiemelten pedig saját partnerükkel) létesített személyes kapcsolatok kialakításának és fenntartásának vágya, averzió a szülôvé válással kapcsolatos változásoktól, valamint a szülói szerep elvetése vagy az arra való képtelenség érzése, illetve az önzôség (Blackstone és Stewart, 2012). Három igen konkrét és a fentiek közül is kiemelkedô motivációs tényezô merül fel gyakrabban a szakirodalomban: a túlnépesedés elkerülésének elôsegítése, a saját boldogtalan gyermekkor emlékei, valamint a szülés fizikai következményeitôl való félelem (Avison és Furnham, 2015).

Gillespie (2003) a fenti tényezóket - vagyis az imént felsorolt motivációs faktorokat - kettôs csoportosítással különítette el egymástól. Számba vett (1) a gyermektelenségre ösztönző (szabadság és kapcsolatok vágya) és (2) a gyermekvállalástól taszító (anyasággal asszociált veszteségek, anyasággal kapcsolatos tevékenységek elvetése) tényezóket. Megközelítésében tehát mérvadónak tekintette, hogy egy adott motívum arra ösztönzi-e az adott személyt, hogy gyermekmentes életet válasszon magának a lehetséges pozitívumok vagy jutalmak okán, melyek ezzel az életformával járhatnak - vagy éppen ellenkezóleg, a gyermekvállalással járó következmények iránti averzió vezeti inkább döntésében.

Ezek alapján elmondható, hogy nagy jelentôsége lehet a gyermekmentes életforma kialakulásában a függetlenedéssel, autonómiával és szabadsággal, valamint a gyermekmentességhez kapcsolódó ideológiákkal kapcsolatos nézeteknek. Meghatározóak lehetnek továbbá az egyén anyai kompetenciáival és felelôsségével, illetve nốk számára jellegzetes nehézségeket tartogató anyai életúttal kapcsolatos elgondolásai. Ezzel együtt a szerzók kiemelik azt is, hogy az önkéntesen gyermektelenekre vonatkozó sztereotip nézetekkel ellentétben a legtöbben nem elsôsorban azért döntenek életformájuk mellett, hogy karrierjükre fókuszálhassanak. Sokkal inkább jellemzônek túnik az, hogy kényelmetlenül érzik magukat gyerekek között, nem találják óket különösebben érdekesnek, netán nem éreznek olyan vágyat a szülôvé válásra, amelyet alapvetônek tartanak a gyermekvállalás tekintetében (Avison és Furnham, 2015). 


\section{Nemi identitás}

Az önkéntesen gyermektelen nôkkel kapcsolatos, nemi identitást érintố kutatások konklúziói egyaránt azt mutatják, hogy a nôk e csoportja a tradicionális, normatív nôi szerepeket elvetố identitással rendelkezik. Fontos azonban kiemelni, hogy a téma szakirodalma alapjában véve heteronormatív, vagyis a heteroszexuálistól eltérô szexuális beállítottságú egyéneket általában nem azonosították, vagy direkt heteroszexuális mintával dolgoztak. Ennek okán jelen írásban a szexuális orientáció és a nemi identitás elkülönítve kerülnek tárgyalásra, utóbbinak heteroszexuális személyekkel folytatott kutatások adják az alapját.

Mollen (2006) azt találta, hogy a vizsgálatában részt vevô önkéntesen gyermektelen nốk nemi szereppel kapcsolatos attitúdjeit gyakran a lázadás vagy ellenállás gondolatai határozzák meg. Eredményei különösen érdekesek fejlôdéslélektani szempontból, ugyanis vizsgálati alanyait nem csupán jelenlegi attitúdjükrốl kérdezte meg, hanem gyermekkori viszonyulásukra vonatkozó adatokat is gyújtött. Ezek alapján úgy találta, hogy ezek a nôk gyakran már gyermekkorukra visszaemlékezve is a hagyományos nối nemi szerepektôl eltérô viselkedésrôl és viszonyulásról számolnak be játéktevékenységük tekintetében. Babákkal való interakciójukat nem határozták meg az anyai szereppel kapcsolatos attitúdök, s amennyiben tehették, a babázós és papás-mamás játékok helyett könyvekkel és nagyobb fizikai aktivitást megkövetelô vagy kinti elfoglaltságokkal töltötték idejüket.

Egy másik kutatás során Newton és Stewart (2013) arra az eredményre jutottak, hogy a nemi szempontból nem normatív életutakat bejáró nốk a konvencionális nôi nemi szerepeknek kevésbé megfelelô személyiségjegyekkel rendelkeznek, és ezt igaznak találták gyermektelen nôk tekintetében is. Vizsgálatuk során középkorú gyermektelen és gyermekkel rendelkezô nôket hasonlítottak össze, és azt találták, hogy a gyermektelen nốk magasabb pontszámot értek el a maszkulin vonások skálán, és szignifikánsan alacsonyabb pontszámot szereztek a feminin vonások skáláján. Emellett gyermekkel rendelkezô társaiknál kevésbé bizonyultak gondoskodónak, femininnek viselkedésükben, illetve kevésbé vágytak megerősítésre másoktól, de szkeptikusabbnak, autonómabbnak és távolságtartóbbnak bizonyultak.

\section{Szexuális irányultság}

A legtöbb, a gyermekmentességgel foglalkozó vizsgálat heteronormatív megközelítésben tárgyalta a kérdéskört; a legtöbb korábbi kutatás elsôsorban vagy kizárólag heteroszexuális nốk gyermekvállalási attitúdjeire fókuszált. Az utóbbi évtizedek törvényi, társadalmi és technológiai változásai azonban egyre elérhetôbbé tették a gyermekvállalás lehetôségét az LMBT közösség tagjai számára is. Ezen folyamatok következtében egyre többen gondolnak közülük a szülôvé válás lehetôségére és egyre többen hozhatnak meg gyermekvállalással kapcsolatos legitim döntéseket.

Gato, Santos és Fontaine (2017) homoszexuális férfiak és nôk gyermekvállalással kapcsolatos döntéseit vizsgáló összefoglaló írásukban számot adnak arról, hogy noha 
egyre több homoszexuális nô és férfi vállal gyermeket az USA-ban, még mindig sokkal kevesebben válnak, illetve vágynak és terveznek a szülôvé válással heteroszexuális társaikhoz képest. Fertilitási döntéseiket több faktor is meghatározza, ezeket a szerzôk az alábbiak szerint négy nagy csoportba sorolták.

Fontos szerepet játszanak a különbözô (1) szociáldemográfiai tényezók (nem, életkor, kohorsz, valamint rassz és etnicitás). Nemi szempontból fontos kérdés egyrészt a háztartáson belüli munkamegosztás és ennek nemi vetületei. Az ezzel kapcsolatos eredmények nem egyértelmúek, a téma további feltárása fontos lehetne ezen tényezó gyermekvállalásra gyakorolt hatásának megértése szempontjából - az viszont elmondható, hogy a homoszexuális nôk nagyobb valószínúséggel vágynak és szándékoznak gyermeket vállalni, mint a homoszexuális férfiak. Életkor és kohorsz tekintetében elmondható, hogy a fiatalabb kohorszba tartozók közül egyre többen gondolnak a szülôvé válásra. Nem tiszta viszont, hogy ez az általános tendencia jogi és egyéb tényezôk függvényében milyen megoszlást mutat. Rasszal és etnicitással kapcsolatban kevés eredmény ismert homoszexuális felnôttek gyermekvállalási intenciói kapcsán - feltételezhetố az interszekcionalitással kapcsolatos szakirodalom alapján, hogy ez a kettôs identitás más és más gyermekvállalási kimenetekkel jár.

Döntésüket meghatározzák továbbá (2) személyes tényezók, így a homoszexuálisok elleni előítéletek internalizáltsága, illetve a személy nyitottsága heteroszexuálistól eltérô beállítottsága kapcsán. Ezek a stigmatizációhoz kapcsolódó tényezók hátráltató hatásúak lehetnek a gyermekvállalásra, ugyanakkor fontos kiemelni, hogy a heteroszexuálistól eltérô identitásnak pozitív aspektusai is lehetnek. Ezen aspektusok hatásai a gyermekvállalási attitúdökre még felderítetlenek, a szerzôk külön felhívják a figyelmet erre a szakirodalmi hiányosságra.

A döntés meghozatalában közrejátszanak továbbá (3) kapcsolati sajátosságok (partner szülôi motivációija és a társas támogatottság mértéke). Egy adott párkapcsolaton belül is eltérô gyermekvállalási motivációkkal bírhatnak a partnerek - ez különösen sok kérdést vethet fel az azonos nemú kapcsolatokban élő személyek döntései kapcsán. Kérdéses, hogy milyen szempontok alapján egyeznek meg a gyermekvállalással kapcsolatos szerepkörök felosztásában - adott esetben ennek jogi (adoptáció) vagy egészségügyi (mesterséges megtermékenyítés) vetületeinek vállalásában. Ami a társas támogatottságot illeti, a szülôvé váló homoszexuális férfiak és nôk egyaránt származási családjaik erốs támogatásáról adnak számot.

Kiemelt jelentôségúek továbbá a (4) kontextuális szempontok (munkafeltételek, LMBT támogató hálózatokhoz, információkhoz és egyéb eróforrásokhoz való hozzáférés, valamint a fennálló szociális, legális és orvosi korlátok). A különbözô diszkriminációk és az ezekhez kapcsolódó munkahelyi körülmények és szabályozások részei lehetnek a gyermekvállalást hátráltató tényezóknek. Pozitív hatással lehetnek viszont a pozitív munkahelyi tapasztalatok, így a kollégák támogatása. Különbözô vizsgálatok eredményei arra mutattak rá, hogy az információs erôforrások, valamint az erre specializált támogató csoportok hozzáférhetôsége nagy hatással lehet a homoszexuális felnôttek gyermekvállalási motivációira. Végül pedig fontos kitérni a szexuális orientációjuk szempontjából kisebbségbe kerülooket sújtó különbözô jogi és társadalmi környezetek hatásaira is - jelenleg nagy változatosság figyelhetô meg kultúránként és országon- 
ként ilyen téren. Emellett a különbözô elôítéletek és az ezekhez kapcsolódó kapuôrök (jelen esetben írott vagy íratlan szabályok) szintén nehezíthetik az örökbefogadási vagy megtermékenyítési folyamatot, s ezáltal a gyermekvállalásra is hatással vannak.

Érdekes megközelítés lehet annak vizsgálata is, hogy vajon a gyermekvállaláshoz vezetô különféle utak során az ezzel kapcsolatos döntéseket befolyásoló tényezôk menynyiben térhetnek el a különbözô és az azonosnemú párok esetében. A szerzók külön kiemelik a biologista ideológiák jelentôségét a kérdéskörben - fontos lehet ugyanis az egyének számára az, hogy milyen biológiai kapcsolatban állnak gyermekükkel és ennek jelentôsége egészen máshogy jelenhet meg homoszexuális és heteroszexuális egyének esetében. Példaként pedig több korábbi vizsgálat eredményeit elevenítik fel. Partnereikhez képest ugyanis egyes leszbikus szülőanyák erôsebb vágyat éreztek a gyermekvállalásra, az elsôdleges gyermekgondozás nagyobb részét ôk vállalták, és bizonyos szinten közelebbinek érezték kapcsolatukat gyermekükkel. Más vizsgálatok a különböző „fordulópontok” jelentôségét emelik ki. Bizonyos esetekben többek között homoszexuális szülők társasága és barátsága, a mások gyermekeivel töltött idô, valamint az egyén saját gyermekvállalási vágyának növekedésével való szembesülés is ilyen fordulópontként szolgálhatnak és nagyban befolyásolhatják az egyén gyermekvállalásra vonatkozó elképzeléseit.

A legtöbb heteroszexuálistól eltérô szexuális orientációval foglalkozó kutatás homoszexuálisok gyermekvállalásával kapcsolatos. Lényegesen kevesebb információ található biszexuális és transzszexuális nôk és férfiak gyermekvállalási attitúdjeirôl. Szintén Gato, Santos és Fontaine (2017) foglalják össze az eddigi eredményeket rövid kitekintésükben. A biszexuális szülők kapcsán egyes szerzők felvetik, hogy a biszexuális identitás nehezen fenntarthatónak bizonyulhat a szülōvé válás folyamata során. Ugyanakkor más vizsgálatok eredményei szerint a biszexuális nôk és férfiak nagyobb eséllyel vágynak gyermekre, mint homoszexuális társaik. Biszexuális anyákkal folytatott beszélgetések fényt derítenek arra is, hogy e két szerepet ezek az anyák képesnek bizonyultak pozitív és egymással kompatibilis szerepként megélni. Ami a transzszexuális személyek lehetôségeit illeti, ôk is számos hátráltató tényezôvel nézhetnek szembe ilyen téren - ezek közé tartoznak a kulturális attitűdök, valamint a lehetôségeiket korlátozó jogi és orvosi szabályozások.

Összességében elmondható, hogy a téma szakirodalma egyáltalán nem teljes, a gyermekmentesség irodalmán belül is kifejezetten hiányos területet alkot. A legtöbb vizsgálat amerikai mintával dolgozott, és ezek fókuszában többnyire nem a gyermekmentesek álltak, hanem a gyermekvállalási attitűdök. Nagy jelentôsége lenne a felvetett kérdéskörök alaposabb vizsgálatának, a gyermekmentességre fókuszáló kutatásoknak, a megkérdezettek köre diverzifikálásának, valamit a nemzetközi és hazai sajátosságok felderítésének is. Ezzel együtt az eddigi vizsgálatok alapján látható, hogy a heteroszexuálistól eltérô szexuális orientációjú személyek gyermekmentességre irányuló döntéseit komplex, specifikus háttértényezôk határozzák meg. 


\section{FEJLŌDÉSLÉLEKTANI MEGFONTOLÁSOK}

\section{Családi háttér}

Az önkéntesen gyermektelen nôk fiatalkori jellemzőinek vizsgálata során Mollen (2006) azt találta, hogy vizsgálati alanyai döntô fontosságúnak írták le gyermektelenségük szempontjából szüleik hatását életükre. Kutatása alapján ennek ellenére sem egyértelmú, hogy pontosan milyen hatások a leginkább meghatározóak ilyen szempontból.

Houseknecht (1979) az önkéntesen gyermektelen nôk fejlődéslélektani vizsgálata során a döntés idôpontján kívül egyéb különbségeket is feltárt a fentebb ismertetett két csoport - a korai kinyilvánítók és a halogatók - között az általa leírt három fố tényezô (többek között a családi háttér) mentén. Kutatásai alapján elmondható, hogy a korai kinyilvánítók a halogatókhoz képest nagyobb pszichológiai távolságot éreztek szüleik és maguk között serdülókorukban, származási családjuk érzelmi melegségét alacsonyabbra értékelték, szüleik teljesítmény iránti elvárásai szigorúbbak voltak, lényegesen gyakrabban döntöttek a végleges sterilizáció mellett, és szignifikánsan többen voltak már túl legalább egy váláson.

Ezzel szemben a halogatók szülei jobban támogatták gyermekük asszertív autonómiára való igényét, átlagosan több, a döntésüket támogató és annak meghozatalában figyelembe vett referenciacsoport veszi ôket körül, és szüleik fegyelmezési mintázataiban is akadtak eltérések a korai kinyilvánítókhoz képest.

A nevelési stílusok mellett még egy szempontból találhatóak különbségek gyermektelenség tekintetében, ez pedig a testvérek hiánya. Kiernan 1989-es vizsgálata során azt találta, hogy míg a testvérek és gyermekek száma között nem áll fenn összefüggés, addig a testvérek hiánya szignifikánsan valószínúbbé teszi a gyermektelenséget. Megerôsíti ezt a feltevést Avison és Furnham (2015) vizsgálata is, mely során azt találták, hogy a testvérszám esetén a két csoport közti eltérés szignifikáns - az önkéntesen gyermektelenek $18 \%$-ának nem volt testvére, míg a gyermekre vágyó csoport esetén ez az arány csupán $10 \%$ volt. Kisebb, nem szignifikáns különbségre világítottak rá a családok mérete között is; a gyermektelenek 40\%-a származott olyan családból, ahol kettônél több a gyermekek száma, a másik csoport esetén pedig $52 \%$ volt ez az arány.

\section{Miller fejlódéslélektani modellje}

Miller (1992) fejlôdéslélektani modellje a gyermekvállalási motiváció kialakulásának fố komponenseit írja le, fejlődési tapasztalatok és pszichológiai jellemzók figyelembevételével. A modell sematikus ábrázolása (6. ábra) reprezentálja Miller kutatásainak eredményét, mely szerint a gyermekkori, serdülôkori és felnôttkori személyiségjegyek és az ezen idôszakokat meghatározó tapasztalatok együttese felelős a gyermekvállalási motiváció kialakulásáért.

A modell alapján a gyermekvállalási motivációra három tényezô van közvetlen hatással: (1) a gyermekkori és serdülôkori tapasztalatok, (2) a felnôttkori tapasztalatok, valamint (3) a felnôttkori személyiségjellemzôk. 


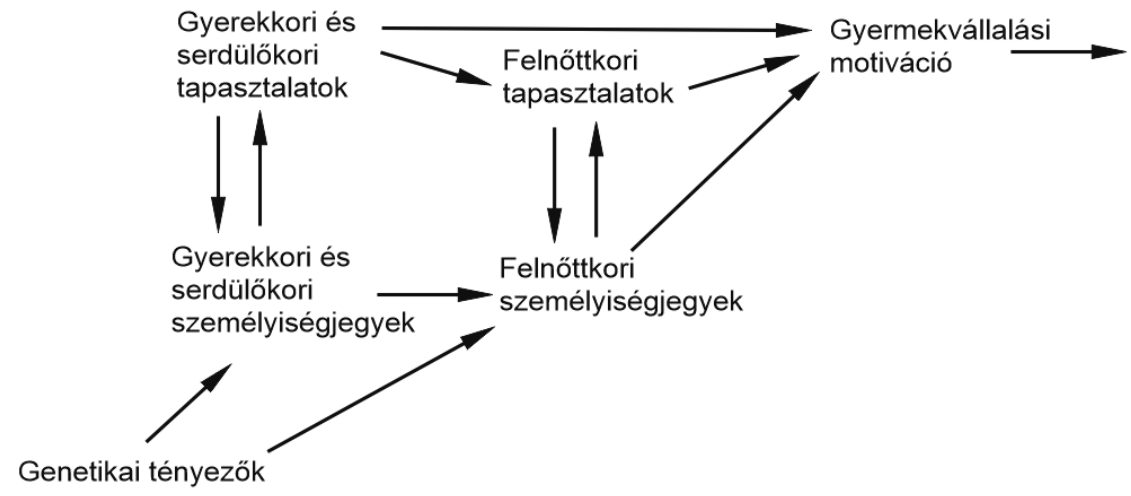

6. ábra. A gyermekvállalási motiváció fejlődéslélektani modellje (Miller, 1992, 268)

Miller a három közvetlen hatású tényező (a gyermekvállalási motiváció szempontjából vett) meghatározóit is kifejti:

(1) Gyermekkori tapasztalatok: Fontos a családi kapcsolatok minósége, a családcentrikus értékek átadása, valamint a modellálás. A jobb, szeretettel teljes családi kapcsolatok, családcentrikus értékek elsajátítása, valamint a szülőkkel és ezáltal a szülôi szereppel való azonosulás mind növelhetik a gyermekvállalási hajlandóságot.

Serdülókori tapasztalatok: A gyermekgondozással kapcsolatos és iskolai tapasztalatok meghatározóak lehetnek. A gyermekgondozási tapasztalatok segíthetnek a gyermekekkel kapcsolatos pozitív élmények szerzésében, míg az iskolai elômenetel és teljesítmény meghatározhatja az egyéni (gyermekvállalással kapcsolatos) célok és képességek alakulását.

(2) Felnôttkori tapasztalatok: A felsôoktatási tapasztalatok, házasság, hivatás, vallás és a folyamatos pozitív kapcsolat a származási családdal szintén meghatározóak. A különbözô társadalmi intézmények szerepe ebben az életkorban igen fontos, és ezek közül is kiemelkedô jelentôségú lehet a gyermektelen életforma választásában a felsôoktatás szerepe. Mind a felsôoktatás, mind pedig egyes hivatások idôbeli „vetélytársai” lehetnek a gyermekvállalásnak, de a vallásosság, a házasság és a származási családdal fenntartott jó viszony a gyermekvállalást segítheti elô.

(3) Felnôttkori személyiségjellemzók: Fontosak a gondoskodási és affiliációs szükségletek, illetve az autonómiára való igény és a teljesítménymotiváció. Az elóbbi két jellemzó a gyermekvállalás, míg az utóbbi kettô a gyermektelenség pozitív megítélésével kapcsolható össze.

Az önkéntesen gyermektelen nôk felnôttkori személyiségjellemzôi alapján gyermekvállalást elôrevetítô kutatásuk során Jokela és munkatársai (2009) konkrétabb eredményeket ismertettek. Megbizonyosodtak arról, hogy az általuk vizsgált három személyiségjellemzô különbözó módon ugyan, de meghatározza a gyermekvállalási szándékot. E három jellemzôt az alábbiak szerint jellemezték: Magas szociabilitásértékkel bír megállapításuk szerint az az ember, aki mások közelségét és társaságát jobban élvezi az 
egyedüllétnél, e jellemzô pedig kapcsolódik az extraverzióhoz. Az emocionalitásérték a neuroticizmushoz kapcsolható és azt reprezentálja, hogy az egyén milyen mértékben fogékony a negativ érzések, így például a félelem vagy a harag megélésére. A félreérthetôség elkerülése érdekében és az itt használt fogalom negatív színezete miatt a továbbiakban ez a jellemzô negatív emocionalitásként kerül említésre. Végül a magas aktivitásszintú egyén jellemzôen energetikusan és élénken viselkedik, napi rutinja is igen aktív.

A gyermekvállalási szándék tekintetében vizsgálataik alapján elmondható, hogy a negatív emocionalitás magas értéke csökkenti a gyerekvállalás valószínúségét, míg a magasabb értékú szociabilitás, illetve férfiak esetében a magasabb aktivitási szint növeli ezt. Vizsgálataik során azt találták továbbá, hogy a személyiség és a gyermekvállalás között kétirányú kapcsolat tárható fel. Tehát a gyerekvállalás tényének is van hatása a személyiségre: a fenti kutatás keretei között azt találták, hogy gyerekvállalás után nôtt a résztvevôk negatív emocionalitásértéke, különösen két vagy több gyerek és magas alapérték esetén.

\section{SZOCIÁLPSZICHOLÓGIAI VONATKOZÁSOK}

\section{Houseknecht szociálpszichológiai modellje}

Az önkéntes gyermektelenséget vállaló nôk Houseknecht (1979) által leírt szociálpszichológiai modellje alapján három meghatározó tényezô játszik szerepet a gyermektelenséggel kapcsolatos döntés meghozatalában: (1) családi háttértényezôk, (2) társas attitúdök (self-other attitudes) és (3) a referenciacsoportok. Modellje szerint a gyermektelenséggel kapcsolatos döntéseket az egyénre egyszerre ható külsô és belsô tényezôk interakciója határozza meg - vagyis az, ahogyan az ốt körülvevô, döntéseit meghatározó személyek és csoportok, valamint saját társas attitúdjei hatnak egymásra. Mindezeket meghatározza az egyén családi háttere, illetve a gyermektelenséggel kapcsolatos döntése maga is hatással bír e két tényezôre (7. ábra).

Családi háttértényezók közé sorolja a szülői dominanciával kapcsolatos tapasztalatokat, a serdülôkorban kialakuló pszichológiai távolság mértékét, valamint az egyén életkorát, amikor elôször megfontolja, hogy szülôvé váljon. Kutatásai alapján ezek a háttértényezôk lehetnek az autonómiaigény és a teljesítménymotiváció kifejlôdésének elsôdleges okozói. Ezen két személyiségjegy pedig összefüggésbe hozható az önkéntes gyermektelenséggel. Több kutatás (Houseknecht, 1979; Miller, 1992) alapján ugyanis az önkéntesen gyermektelenek magasabb autonómiaigénnyel és magasabb teljesítménymotivációval rendelkeznek gyermeket vállalni vágyó társaiknál, illetve e két tulajdonság és a gyermektelen életmód preferenciájának együttes megléte esetén megnövekszik a valószínúsége annak, hogy ezek a személyek e mellett az életmód mellett döntenek. Ennek valószínúségét Houseknecht szerint növeli a referenciacsoportok fenntartott támogatása is.

A referenciacsoportokkal kapcsolatos korábbi vizsgálata során Houseknecht (1977) arra a következtetésre jutott, hogy az önkéntesen gyermektelenek nem csupán a domináns társadalmi normától való deviáció mentén jellemezhetôek. Ezzel párhuzamosan ugyanis jellemzôen konformitást mutatnak más referenciacsoportok fertilitással 


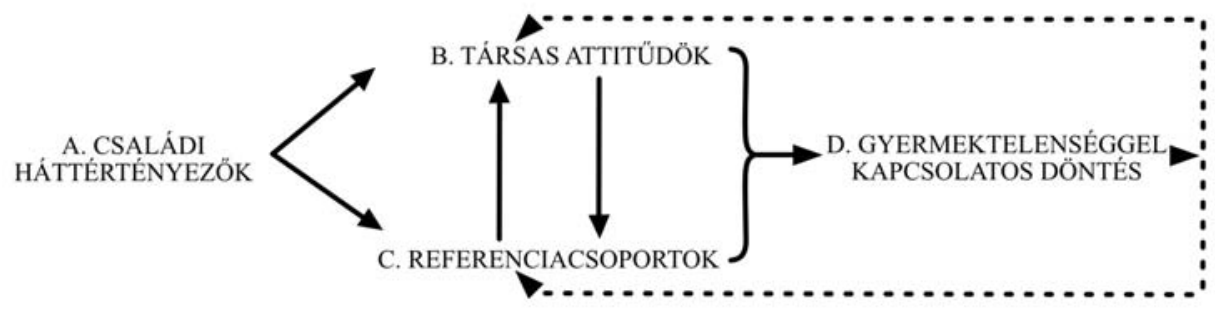

A. CSALÁDI HÁTTÉRTÉNYEZÖK

1. Szülöi dominancia

2. Pszichológiai távolság alakulása a családtól serdülökorban

3. Életkor, amikor a személy elöször megfontolta a szülövé válást
B. TÁRSAS ATTITÜDÖK

1. Autonómia

2. Szülövé válással és gyerekekkel kapcsolatos attitüd

3. Alternativ szerepkörök ismerete és elfogadása

4. Nöjogi mozgalommal való identifikáció

5. Életcélok

C. REFERENCIACSOPORTOK (család, barátok, csoportok és szervezetek)

7. ábra. Az önkéntes gyermektelenség szociálpszichológiai modellje (Houseknecht, 1978, 394)

kapcsolatos, a saját attitúdjeikkel egyezô normái felé. Eredményei szerint a gyermektelenség mellett határozók és a gyermeket vállalni vágyók között szignifikáns különbség áll fenn az alapján, hogy milyen a gyermektelenséget támogató nézetek aránya az általuk figyelembe vett referenciacsoporton belül. Az önkéntesen gyermektelenek referenciacsoportjaiban nagyobb arányban jelentek meg a gyermektelenséget támogató nézetek, illetve kisebb arányban szerepeltek a gyermekmentességet elítéló attitûdök, mint a gyermeket vállalni vágyók csoportjaiban. A gyermekvállalási attitûdök szempontjából figyelembe vett személyek nézetei tehát kongruensnek bizonyultak a vizsgálati személy beállítottságával.

A társas attitüdök Houseknecht modelljében magukban foglalják az egyén autonómiára való igényének mértékét, a szülôvé válással kapcsolatos attitûdjeit, azt, hogy mennyire ismeri és fogadja el a különböző alternatív szerepköröket, hogy mennyire azonosul a nôjogi mozgalommal, illetve mik az életcéljai. Tulajdonképpen értelmezhetô úgy, mint annak mértéke, hogy az egyén attitúdjeiben és viselkedésében menynyire függ a különbözó társas hatásoktól. Érdemes kiemelni a társas attitúdök szempontjából jelentôs eredményét, mely szerint a gyermekmentes nôk autonómia iránti igénye magasabb a gyermekre vágyókénál, és a döntéseiket meghatározó referenciacsoportok száma is alacsonyabb. Ez a számbeli eltérés nem csupán fertilitással, hanem általános értelemben vett döntéseik társas meghatározottságával kapcsolatban is megállta a helyét (1978).

\section{Az önkéntes gyermektelenség társadalmi megítélése: sztereotípiák, attitüdök}

A gyermekmentes életmódot választókkal kapcsolatos nézeteket a negatív vélekedések túlsúlya jellemzi: a szélsôséges nemtetszéstôl a lenézésen és sajnálaton át egészen a deviánsnak nyilvánításig megannyi attitúdre található példa az utóbbi évtizedek szakiro- 
dalmában. Igaz ugyanakkor az is, hogy egyes vizsgálatok növekvô toleranciáról adnak számot a felnôtt életutak diverzifikációjának tekintetében (Thomton és Young-DeMarco, 2001).

Ennek ellenére több szerzô arról számol be, hogy az önkéntesen gyermektelen nók továbbra is speciális társadalmi és pszichológiai szankciókkal kénytelenek szembenézni. Gyermekvállalással kapcsolatos elhatározásuk és nemük között egyfajta interszekcionalitás áll fenn, vagyis ezen két tényezô együttes hatása determinálja az ôket érô megkülönböztetés pontos mibenlétét. Ezek a specifikus negatív sztereotípiák és társas nyomások még mindig jelen vannak, és napi szinten hatással vannak rájuk a legtöbb nyugati kultúrában (Laegeforen, 2002; Letherby, 2002; Park, 2002).

Anyákkal és akaratukon kívül gyermektelenül maradó társaikkal, valamint a hozzájuk hasonló döntésre jutó férfiakkal összehasonlítva is egyaránt negatívabb a megítélésük (Bays, 2016). Nemük miatti nehézségeik oka lehet az, hogy a nyugati kultúrák nôideálja szorosan kapcsolódik az anyaság intézményéhez; nem csupán a szülővé válás, hanem kiemelten az anyai szerep is fontos része a szociális normatíváknak (Russo, 1976; Gillespie, 2003), sôt, a legújabb kutatások alapján a szülővé válás bizonyos kultúrákban erkölcsi kötelesség (Ashburn-Nardo, 2016). Ennek okán a gyermektelenség mellett határozók könnyen érezhetik magukat kitaszítottnak, egy külsó csoport részének, ráadásul gyakran szembesülnek nôi identitásukhoz szorosan kapcsolódó, azt megkérdôjelezó előítéletekkel: „...gyakran nevezik ôket nôiségükben beteljesületlennek; önzônek, üresnek, emocionálisan és pszichológiailag éretlennek” (Gotlib, 2016). Az egyetlen olyan csoport, mely még az önkéntesen gyermekteleneknél is inkább ki volt téve a gyermekvállalással kapcsolatos stigmatizációnak, az a terhességük miatt boldogtalan kismamák csoportja (Ashburn-Nardo, 2016).

Összegzésképpen elmondható, hogy a gyermektelenség mellett határozó nóket mások gyakran gyerekesnek, materialisztikusnak, önzőnek, kiegyensúlyozatlannak és deviánsnak látják. Úgy gondolják róluk, hogy valamiféle baj van velük, és anyává váló társaiknál hûvösebbek. Összehasonlítva óket a gyermekre vágyó nôkkel, azt feltételezik róluk, hogy kisebb eséllyel élhetnek boldog és elégedett életet (Bays, 2016; Blackstone és Stewart, 2012). Megítélésük jellegével a gyermektelen nôk maguk is tisztában vannak; beszámolóik alapján gyakran szembesülnek stigmatizációval, úgy érzik, hogy sajnálják ôket, döbbenettel vagy rosszallással szembesülnek, figyelmen kívül hagyják vagy kritizálják választásukat, nyomást gyakorolnak rájuk és igyekeznek meggyốzni óket arról, hogy gyermeket kellene vállalniuk (Bays, 2016). Veevers (1975) szerint a gyermektelenek erre a fajta pszichés teherre válaszul kétféle megküzdési mechanizmust alkalmaznak: (1) a társas normákhoz közelítô módon kommunikálnak (pl. örökbefogadási lehetôségekrôl beszélnek), vagy (2) olyan morális standardokat sajátítanak el, melyek az anyaság intézményével direkt ellentétesek (pl. túlnépesedésre hivatkoznak). Késóbbi kutatások során Park (2002) defenzív/reaktív és proaktív technikákat említett - míg az elóbbivel élók elfogadták a pronatalista normákat, az utóbbiakkal élôk az önkéntes gyermektelenséget egy társadalmilag elfogadott életstílusként fogadták el. A két véglet között említésre érdemesek a szerzó által közbeesônek nevezett technikák, melyek a konvencionális ideológiákat kérdőjelezték meg. Houseknecht (1977) pedig a társas támasz fontosságát emelte ki ilyen téren. 
A pszichológiai következmények mellett fontos kiemelni, hogy ezek a negatív nézetek más módon is a gyermektelenek mindennapjainak részévé válhatnak. Egyes vizsgálatok alapján a gyermektelen munkatársaktól több és kellemetlenebb idôpontokban befektetett munkaórát várnak el, nagyobb valószínúséggel várják el a hétvégén és ünnepnapokon való munkát, esetenként rosszabb feltételekkel kell szembesülniük (Bays, 2016), és több munkahelyi zaklatás érheti óket gyermeket nevelô társaikhoz képest (Ashburn-Nardo, 2016). Kifejezetten a gyermektelenséget választó nôket sújtó nehézség, hogy egyes orvosok megtagadják a sterilizálásukat, megalázzák ôket vagy fölöslegesen bonyolult procedúrává teszik a beavatkozás igénylésének folyamatát (Richie, 2013).

\section{Társadalmi különbségek jelentösége}

A társadalmi megítélés nagyban függhet az adott társadalom értékrendszerétôl. Pronatalista társadalmak esetén ennek normatív funkciója a gyermekvállalás ösztönzését célozhatja. Fontos azonban kiemelni, hogy az adott társadalom sajátosságai nagyban meghatározhatják azt, hogy annak tagjai milyen megítélésben részesülnek. Éppen ezért a különbözô társadalmak közti különbségeknek nagy jelentôsége lehet az önkéntesen gyermektelenek társadalmi megítéléssel kapcsolatos tapasztalatai szempontjából.

Egyes, a gyermektelenséggel kapcsolatos attitúdkutatások, köztük a European Values Survey 1999-es és 2008-as adatai is alátámasztani látszanak a korábban taglalt attitűdökkel kapcsolatos eredményeket. A legtöbb vizsgált országban a megkérdezettek jelentôs része egyetért azzal az állítással, hogy „a teljes élet érdekében minden nônek gyermekre van szüksége" (8. és 9. ábra). Igaz azonban az is, hogy Észak- és NyugatEurópa, Kanada, Ausztrália és az USA területén élook lényegesen kevésbé értettek egyet ezzel a kijelentéssel, megfigyelhetố tehát egyfajta kettôsség ezekben az eredményekben. Hasonlóan területi alapon nagyban eltérô eredmények születtek egy másik, de témájában kapcsolódó felmérés során. A felmérésben részt vevôk nagy arányban értettek egyet azzal az állítással, hogy „a gyermeknemzés társadalmi kötelezettség” számos, elsôsorban kelet-európai országban, ugyanakkor Észak- és Nyugat-Európa egyes régióiban sokkal alacsonyabb volt ez az arány (10. ábra).

Érdemes figyelembe venni ebben az esetben a megjelenített adatok két sajátosságát is. Egyrészt a legfrissebb adatok is tíz éve kerültek rögzítésre, míg a régebbiek csaknem húszévesek. Ezzel együtt elmondható az is, hogy ezen attitûdök időbeli alakulása helyenként számottevố változásokat eredményezett az itt feltüntetett időintervallumok tekintetében is. Hazánkat kiemelve ilyen tekintetben látható, hogy 1990-ben a lakosság 96\%-a értett egyet a kijelentéssel, mely szerint „a teljes élet érdekében minden nônek gyermekre van szüksége”, míg 2008-ra ez az arány 87\%-ra csökkent. Mint oly sok, a témával kapcsolatos kutatás esetén, úgy jelen esetben is kiemelhetô konklúzió az, hogy fontos lenne megismételni ezeket a kutatásokat és frissíteni az adatsorokat a relevánsabb eredmények és következtetések érdekében.

Más kutatások eredményei tovább árnyalják a gyermekmentesség megítélése szempontjából fontos kontextuális tényezóket. Tanaka és Johnson (2016) vizsgálata több 


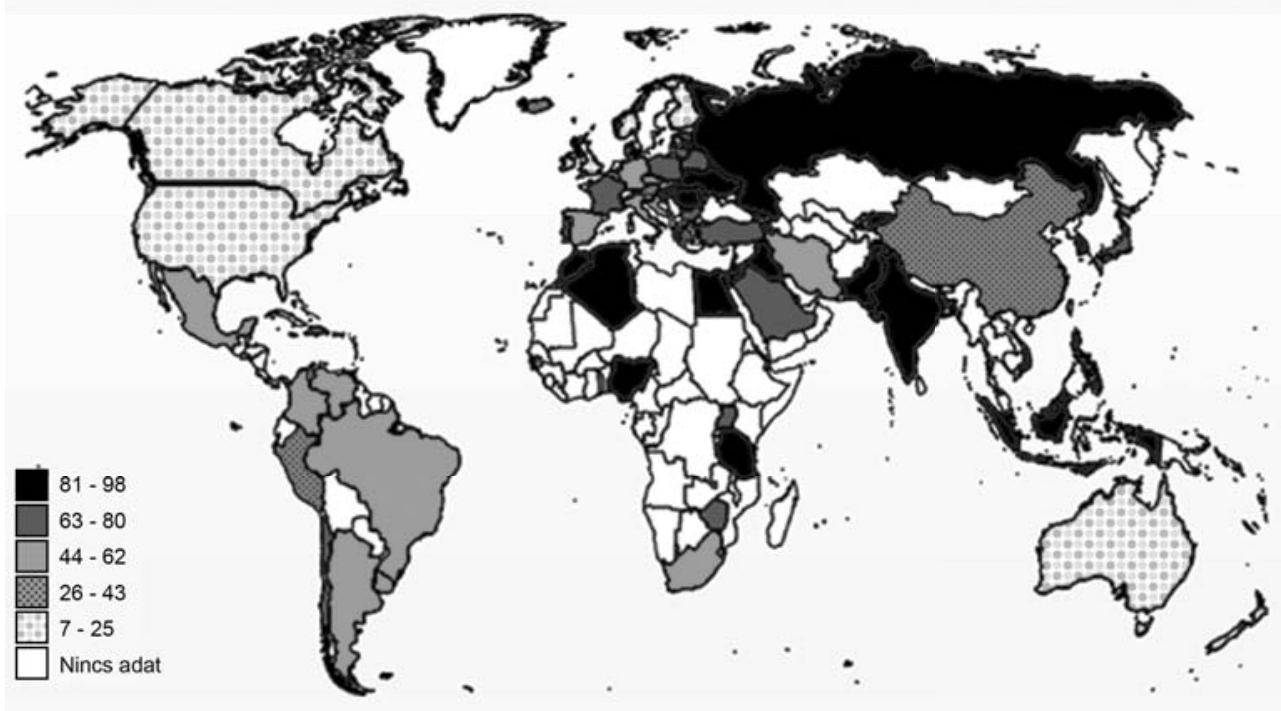

8. ábra. Azon személyek aránya országonkénti bontásban, akik egyetértenek az alábbi állítással: „A teljes élet érdekében minden nőnek gyermekre van szüksége”

(European Values Survey, 1999)

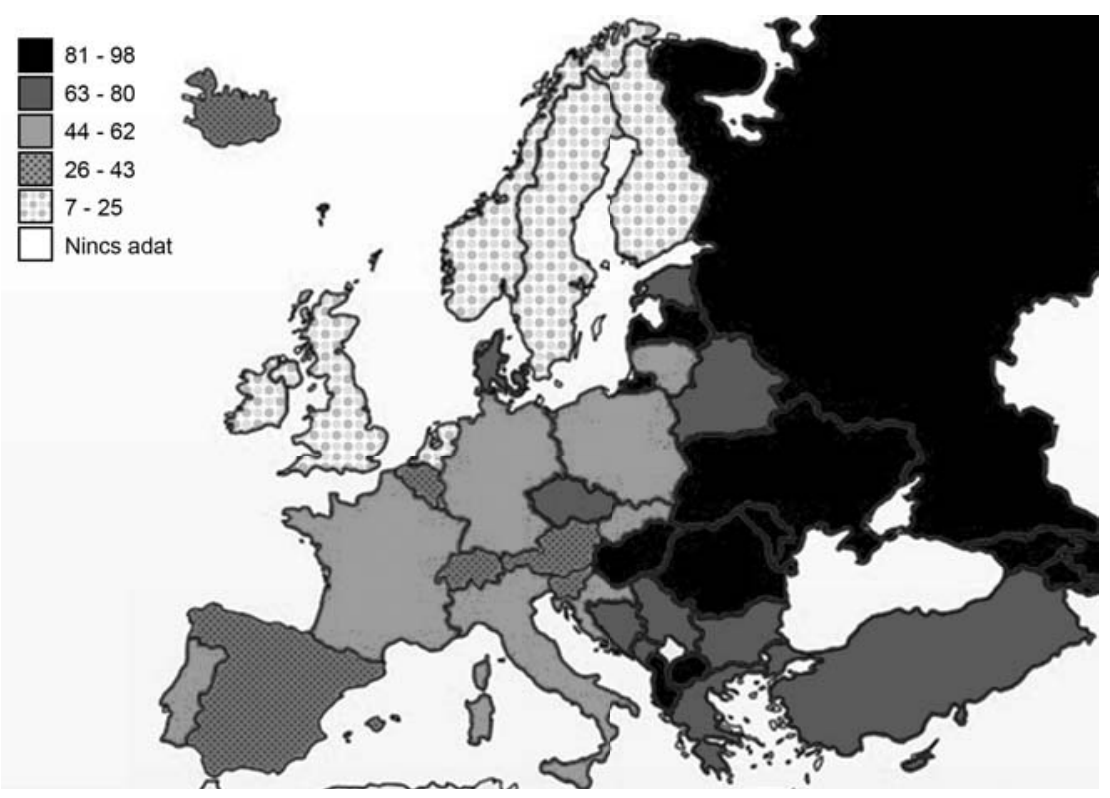

9. ábra. Azon személyek aránya országonkénti bontásban, akik egyetértenek az alábbi állítással: „A teljes élet érdekében minden nônek gyermekre van szüksége”

(European Values Survey, 2008) 


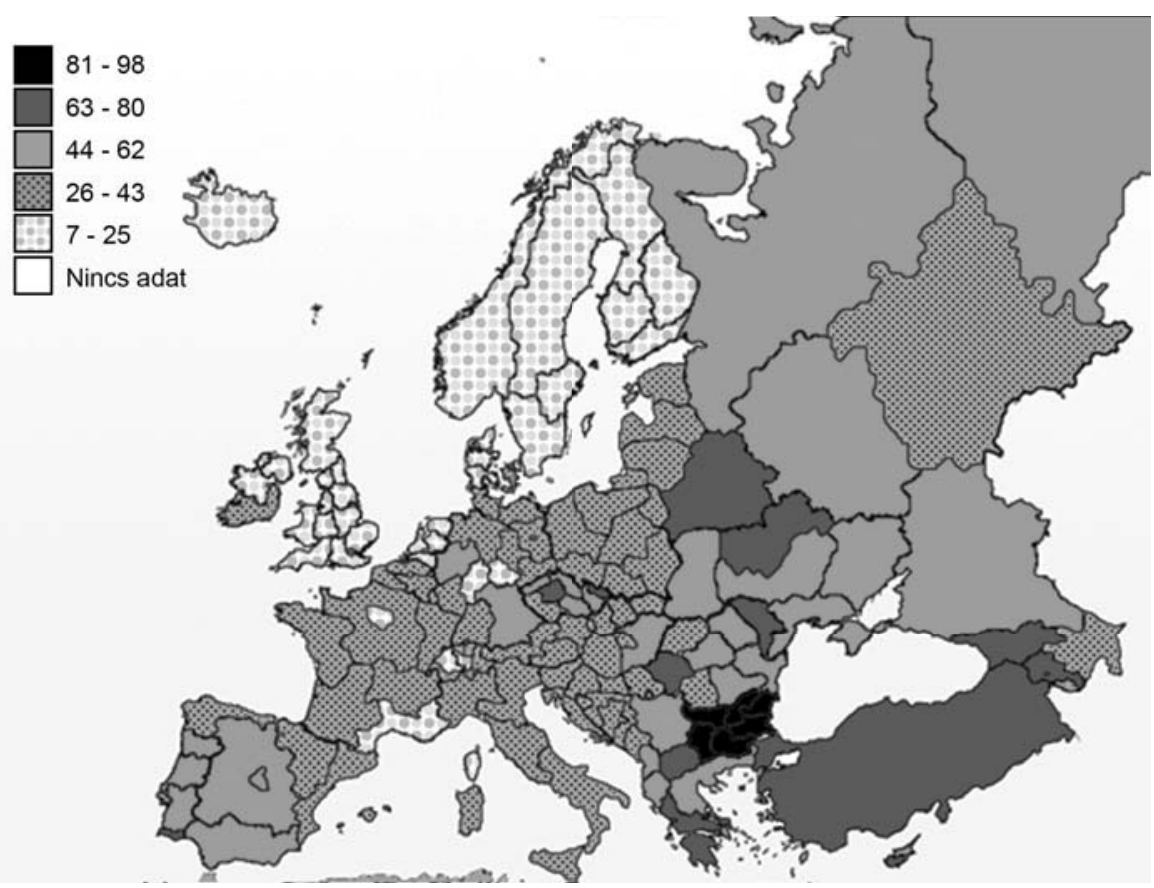

10. ábra. Azon személyek aránya országonkénti bontásban, akik egyetértenek az alábbi állítással: „A gyermeknemzés társadalmi kötelezettség” (European Values Survey, 2008)

olyan tényezôt is feltárt, melyek befolyásolhatják a gyermekmentesekkel kapcsolatos attitúdöket. Az egyik legjelentôsebb determinánsnak az bizonyult, hogy az egyén menynyire pronatalista országban él. Az erôsen pronatalista országokban éló gyermektelen válaszadók kevésbé érezték magukat boldognak és kevésbé voltak elégedettek az életükkel, mint azok, akik enyhébben pronatalista országokban éltek. Meghatározónak találták azt is, hogy az adott ország milyen helyen áll az emberi fejlettségi indexen (Human Development Index) - vagyis az index által mért születéskor várható élettartam, az írástudás, az oktatási, valamint életszínvonal alapján hogyan teljesít más országokhoz képest. Az indexen alacsonyabb pontszámot elérô országokban élô gyermektelen személyek boldogtalanabbak voltak az egyéb országokban élókhöz képest. Azok a gyermekmentes személyek, akik olyan erôsen pronatalista országban éltek, ahol a fertilitási ráta nem haladta meg a népesség fenntartásához szükséges szintet, kevésbé voltak boldogok és elégedettek életükkel, mint azok, akik hasonló fertilitási szintû, de enyhén pronatalista országban éltek.

A kérdéskörhöz szorosan kapcsolódó, hiánypótló jelentôségú Rijken és Merz (2014) tanulmánya, mely a gyermekmentesség elutasítottságának területi megoszlásával is foglalkozik. Kutatásuk során az egyes európai országok nemi egyenlôségének mértéke (GEM), az egy foóre jutó GDP, az önkéntes gyermektelenség átlagos elutasítottsága, valamint a kettôs elvárások kerültek feltárásra (3. táblázat). A nemi egyenlôség mértékének megállapításához a 2008-as United Nations Development Programme 
3. táblázat. Nemi egyenlôség, elutasítás és kettôs elvárások, ország szerint

(Rijken és Merz, 2014, 476)

\begin{tabular}{l|c|c|c|c|c}
\hline Ország & GEM 2006 & GDP 2006 & $\begin{array}{c}\text { Önkéntes gyermek- } \\
\text { telenség átlagos } \\
\text { elutasítottsága }\end{array}$ & $\begin{array}{c}\text { Kettós } \\
\text { elvárás }\end{array}$ & $\mathrm{N}$ \\
\hline Ukrajna & 4.6 & 2.9 & 4.38 & -0.02 & 1,882 \\
\hline Oroszország & 4.9 & 4.5 & 4.16 & 0.06 & 2,156 \\
\hline Románia & 5.0 & 3.8 & 3.77 & -0.02 & 1,943 \\
\hline Magyarország & 5.7 & 6.5 & 3.63 & 0.05 & 1,343 \\
\hline Ciprus & 5.8 & 9.3 & 3.72 & $0.15^{*}$ & 938 \\
\hline Bulgária & 6.1 & 3.7 & 4.44 & 0.03 & 1,254 \\
\hline Lengyelország & 6.1 & 5.3 & 3.38 & -0.05 & 1,657 \\
\hline Szlovénia & 6.1 & 8.9 & 3.15 & $-0.18^{* *}$ & 1,361 \\
\hline Lettország & 6.2 & 5.6 & 3.63 & -0.03 & 1,690 \\
\hline Szlovákia & 6.3 & 6.4 & 3.58 & 0.01 & 1,566 \\
\hline Észtország & 6.4 & 6.8 & 3.95 & -0.06 & 1,462 \\
\hline Belgium & 6.5 & 12.3 & 2.49 & $-0.18^{* * *}$ & 1,784 \\
\hline Svájc & 6.6 & 13.6 & 2.86 & $-0.11^{* *}$ & 1,769 \\
\hline Portugália & 6.9 & 7.4 & 2.93 & -0.02 & 2,107 \\
\hline Írország & 7.0 & 14.3 & 2.99 & $-0.16^{* * *}$ & 1,437 \\
\hline Franciaország & 7.2 & 11.3 & 3.12 & $-0.25^{* * *}$ & 1,965 \\
\hline Egyesült Királyság & 7.8 & 11.9 & 2.79 & $-0.12^{* * *}$ & 2,343 \\
\hline Ausztria & 7.9 & 12.9 & 3.09 & 0.01 & 2,113 \\
\hline Spanyolország & 7.9 & 10.2 & 2.89 & $-0.14^{* *}$ & 1,840 \\
\hline Németország & 8.3 & 11.4 & 3.15 & -0.04 & 2,753 \\
\hline Hollandia & 8.6 & 13.2 & 2.20 & $-0.14^{* *}$ & 1,841 \\
\hline Dánia & 8.8 & 12.7 & 1.67 & -0.07 & 1,448 \\
\hline Finnország & 8.9 & 11.6 & 2.47 & $-0.40^{* * *}$ & 1,875 \\
\hline Norvégia & 9.1 & 18.7 & 2.10 & $-0.14^{* *}$ & 1,722 \\
\hline Svédország & 9.1 & 12.0 & 2.51 & $-0.40^{* * *}$ & 1,866 \\
\hline & & & & & \\
\hline
\end{tabular}

felmérést használták fel, mely a politikai és gazdasági részvétel és döntéshozatal, illetve a gazdasági források feletti hatalom terén tapasztalt egyenlootlenségek mentén, egy 0 (egyenlôtlenség) és 10 (egyenlôség) közötti skálán jeleníti meg a nemi egyenlôtlenség mértékét. Az önkéntes gyermektelenség átlagos elutasítottsága ötfokú skálán került rögzítésre, ahol 1 (erôsen helyesel) és 5 (erôsen elutasít) értékek között, növekvô értékekkel az elutasítás növekvô mértéke reprezentálható. A kettôs elvárások pedig az önkéntesen gyermektelen nôk és önkéntesen gyermektelen férfiak iránti átlagos elutasítás mértékének különbsége alapján kerültek kiszámításra. A negatív értékek ebben az esetben a férfiakra vonatkozó szigorúbb elvárásoknak felelnek meg, míg a pozitív értékek a nôket érintő szigorúbb elvárásokat reprezentálják.

Eredményeik alapján a nemi egyenlőség nagyobb mértékével a gyermekmentesség elutasítottsága átlagosan alacsonyabb értékeket mutat. Ezzel együtt viszont a nagyobb nemi egyenlôségú országokban a kettôs elvárások szintje is magasabbnak bizonyult. A legtöbb, nemi egyenlôség terén elôrehaladott országot a gyermekmentes nôk iránti 
magasabb tolerancia jellemezte, míg a kommunista blokk országai esetén Szlovéniát leszámítva nem találtak szignifikáns különbségeket a gyermekmentes nôk és férfiak megítélésében. Elmondható tehát, hogy a korábban ismertetett vizsgálatokkal éppen ellentétesek ezek az eredmények, ugyanis ezek alapján nem a nôket ítélik meg szigorúbban a legtöbb európai országban gyermekmentességük kapcsán, hanem a férfiakat. Érdemes ennek mentén az önkéntesen gyermektelen férfiakkal kapcsolatos attitûdök kapcsán született kutatási eredményekrôl is értekezni, s feltárni az ezen kettôsség mögött álló lehetséges okokat.

\section{Önkéntesen gyermektelen férfiak}

Sok esetben a szakirodalom nem tesz különbséget a gyermekmentes férfiak és nôk megítélése között - esetenként nemektôl független kérdőívekkel vizsgálják a gyermekmentes személyeket, máskor kizárólag nókre fókuszálnak (Rijken és Merz, 2014). Amennyiben mégis megjelennek velük kapcsolatos vizsgálatok, a szakirodalom sok esetben a nôi fogamzásgátlás akadályaként, vagy a nôket teherbe ejtôkként írja körül szerepüket (Slauson-Blevins és Johnson, 2016). Elmondható azonban az is, hogy a gyermekmentesek megítélésében nemi szempontból fennálló különbségek fontosságára különbözô szerzốk már a téma korai irodalmában is rávilágítottak, s több esetben is foglalkoztak ezekkel.

Jamison, Franzini és Kaplan (1979) kutatásuk során gyermekmentes személyekról és kétgyermekes szülôkrôl szóló szövegrészleteket mutattak be a vizsgálatban részt vevôknek, majd ezek értékelésére kérték ôket. A bemutatott fiktív személyek között férfiak és nôk egyaránt szerepeltek és az értékelések eredményeit a fertilitási attitûdök közti különbségek mentén hasonlították össze. Eredményeik alátámasztották a jelen tanulmányban már ismertetett sztereotipikus következtetéseket; a gyermekmentes férfiak és nôk értékelése szignifikáns eltéréseket mutatott a szülôkétôl több téren is. Nemtôl függetlenül kevésbé tartották ôket érzelmileg kiegyensúlyozottnak és önzóbbnek, illetve atipikusnak minôsítették óket. A férfiak esetében ezen túlmenôen egyéb szignifikáns különbségeket is láttak a résztvevôk; kevésbé érzékenynek és szeretônek ítélték óket, illetve úgy vélték, hogy kevésbé kielégítô az életük az apákéval szemben. Ezek a különbségek nôknél is megjelentek, de nem bizonyultak szignifikánsnak. A gyermekmentes nôket viszont szignifikánsan kevésbé látták boldognak, mint az anyákat, de ez a különbségtétel nem jelent meg gyermekmentes férfiak és az apák esetében. A szerzők külön kiemelték a férfiakra irányuló kiemelten negatív ítéleteket, melyek a korábbi feltételezésekkel és kutatásokkal ellentétesek.

Az elsố nagy nemzetközi mintával dolgozó felmérés, amely az önkéntesen gyermektelen férfiakat és nôket érô megkülönböztetések különbözôségével foglalkozik, Rijken és Merz (2014) korábban már ismertetett kutatása. Eredményeik párhuzamba állíthatóak az imént ismertetett ítéletek súlyosságával; a szakirodalom nagyobb részének korábbi feltételezéseivel és kijelentéseivel ellentétes módon arra mutattak rá, hogy az önkéntes gyermektelenség a vizsgált országokban általában véve elfogadottabb nôk, mint férfiak esetén. Arra is rámutattak, hogy ezt a nemi alapú kettôs elvárást leginkább az európai nốk tartják fenn - az ô megítélésük pozitívabb a gyermekmentes 
nôk tekintetében. Ezzel szemben a férfiak megítélése nem mutatott szignifikáns nemi alapú különbségeket, vagyis az európai férfiak hasonlóan ítélik meg az önkéntesen gyermektelen nôket és férfiakat. Ez a különbség tehát kizárólag a gyermekmentes nôk megítélésének különbözôsége miatt lépett fel, ugyanis a nôk általában toleránsabbak a gyermekmentes nókkel szemben, míg a férfiak tekintetében nincsen szignifikáns különbség nôk és férfiak róluk alkotott véleménye között. A tanulmány értelmezése szerint feltételezhetô, hogy ez a különbségtétel a nôk gyermekvállalás általi magasabb fokú érintettsége miatt lehet. Ezen érvelés szerint, mivel a gyermekvállalás személyes és szakmai szempontból is több erôfeszítést igényel a nôk részérôl, az ô gyermekmentességük érthetôbb és elfogadhatóbb - különösen más nók által. Ezekhez az eredményekhez kapcsolható Tanaka és Johnson (2016) kutatása, mely során úgy találták, hogy az önkéntesen gyermektelen résztvevók közül a férfiak boldogtalanabbak voltak, és életükkel is kevésbé voltak elégedettek.

Látható ezek alapján, hogy a férfiak szerepe az utóbbi idôben egyre inkább felértékelôdni látszik a gyermekmentesség szakirodalmában, de még mindig alulreprezentáltság jellemzi ezt a kérdéskört. Az önkéntesen gyermektelen férfiakkal kapcsolatos kutatási látképre (részben) magyarázatot adhat Slauson-Blevins és Johnson 2016-os cikke, melyben a férfiak alacsony arányú részvételének okait igyekeztek feltárni. Írásukban kiemelik, hogy a gyermekvállalással kapcsolatos kutatásokra kifejezetten jellemzô, hogy szignifikánsan kevesebb férfi vesz részt ezekben, mint nô. Korábbi feltételezésekkel egybehangzóan megállapították, hogy a kutatási folyamat során „kapuôrök” szerepében fellépố nôk tevékenysége (kutatásban való részvételük után nem biztosították férjük részvételét ugyanazon kutatásban), illetve a választ valamilyen okból elkerüló férfiak viselkedése is indokolhatja ezt a nemi alapú aszimmetriát. Eredményeik alapján a jelenség hátterében álló legfontosabb mechanizmus mindkét lehetséges magyarázat esetén a reprodukciós kérdéseket nôi területként értelmezô ítéletek hatása volt. A szerzôk értelmezésében több tényezô is alátámasztani látszik ezt a következtetést. Azok a nôk, akik hagyományosabban vélekedtek a nemi szerepekkel kapcsolatban, gyakrabban léptek fel kapuőrök szerepében, míg azok a férfiak, akiknek a párja vetélésen esett át az utóbbi idóben, kisebb eséllyel vettek részt kutatásokban.

\section{ÖSSZEFOGLALÁS, KITEKINTÉS}

Az önkéntes gyermektelenség témakörében végzett, jelen tanulmányban ismertetett kutatások mozaikossága, a téma összetettsége és relatíve keveset vizsgált összefüggései miatt belátható, hogy nehéz konzekvens és koherens képet alkotni errôl a komplex és sok határterülettel bíró kérdéskörrôl. Ennek ellenére a fentebb áttekintett vizsgálatok, elméleti és módszertani megközelítések, valamint metaanalízisek mindegyike hasznosnak tekinthetô abban az értelemben, hogy releváns és a témához erôsen kötôdô információkat szolgáltat.

A felsorakoztatott szakirodalom alapján felismerhetôvé válhat néhány valóban figyelemreméltó tendencia mind a téma, mind pedig az ezzel kapcsolatos vizsgálatok tekintetében. Mindenekelốtt megfigyelhetô, hogy a legtöbb vonatkozó kutatás nôkre irányul (1. táblázat), és még ha szerepelnek is férfiak a vizsgálati mintában, helyzetük 
és nemi sajátosságaik általában csupán periférikusan nyer említést. Ennek okai között azonban nem kizárólag a kutatások vezetôinek elfogultsága sejthetô, hiszen jól ismert nehézsége a gyermekvállalással kapcsolatos kutatásoknak, hogy ezekben szisztematikusan alacsonyabb a férfiak részvételi aránya (Slauson-Blevins és Johnson, 2016). Részben emiatt kerültek jelen írás fókuszába az önkéntesen gyermektelen nôk. Másrészt viszont az anyai szerep és az ezzel járó nôi nemiszerep-elvárások, illetve a családi szerepeknek az élet egyéb területeihez képest lassabban zajló változása egyaránt a nôk gyermektelenségi döntését helyezheti előtérbe; talán ennek is köszönhető, hogy a vizsgálatok jelentôs része rájuk irányul. Noha még nôk esetén sem mondható, hogy a téma minden tudományos elvárást teljesító mélységben feltárt, kétségtelen, hogy az önkéntesen gyermektelen férfiak, illetve a heteroszexuálistól eltéró szexuális beállítottságú nôk és férfiak pszichés jellegzetességei további szisztematikus vizsgálatra szorulnak.

Pszichológiai szempontból releváns következtetésekre ezek alapján tehát legfeljebb a gyermekmentes nôk esetében juthatunk, még pontosabban közülük is csupán a WEIRD társadalmak tagjaira nézve. A WEIRD mozaikszó a nyugati, múvelt, indusztrializált, gazdag és demokratikus (western, educated, industrialized, rich and democratic) társadalmak leírására használható, és észrevehetô az itt felhasznált vizsgálati anyagok áttekintésekor is, hogy az ezekben leírt kutatások jelentôs része e kategóriába sorolható társadalmú országokban készült (1. táblázat). Nem hagyható figyelmen kívül, hogy e vizsgálati anyagok validitása ilyen szempontból is korlátozott, az egyéb társadalmi sajátosságokkal bíró országokban kivitelezett, az ehhez a témához kapcsolódó kutatások száma pedig igen alacsony (McAllister, Pepper, Virgo és Coall, 2016).

Ilyen korlátok mellett az önkéntesen gyermektelen nók személyiségének tekintetében úgy tûnik, hogy gyermektelenségük szándéka korrelációt mutat negatív emocionalitásuk mértékével (Jokela és mtsai, 2009), illetve Avison és Furnham (2013, 2015) felmérése alapján önállóbbak, magas autonómiaigény jellemzi ôket, a különbözô eszmék iránt nyitottabbak, míg szociális kapcsolataik tekintetében kevésbé barátságosak és extrovertáltak, mint gyermekre vágyó társaik. Emellett neurotikusabbak, és magas teljesítménymotivációval jellemezhetőek. Ezen a ponton, még az eredmények értelmezése elôtt szükségszerû említést tenni két kritikai élú észrevételrôl is.

Avison és Furnham $(2013,2015)$ felmérésének pontossága és módszertana kapcsán megemlítendő, hogy mintavételezési eljárásuk több kérdést is felvethet. Kutatásuk során elsôsorban önkéntesen gyermektelen résztvevôket kértek online kérdôívük kitöltésére, és mintegy mellékesen részt vehettek gyermekre vágyó személyek is. A résztvevốk nemi és nemzeti megoszlása sem sugall reprezentatív mintavételezésre törekvô eljárást, mintájuk 91\%-át ugyanis nôk alkotják, és noha a nemzettôl független mintára törekedtek, angol nyelvú felmérésük legtöbb résztvevôje az Egyesült Államokból és az Egyesült Királyságból került ki. Vizsgálatuk eredményei viszont egybevágnak több hasonló fókuszú kutatás következtetéseivel (Houseknecht, 1979; Miller, 1992; Jokela és mtsai, 2009), illetve összehasonlíthatónak és összekapcsolhatónak tûnnek a gyermektelenséget választók motivációs bázisát feltáró vizsgálatok eredményeivel. Ezek ugyanis a függetlenség, önállóság és autonómia vágyát (Blackstone és Stewart, 2012), illetve a gyermekvállalástól taszító tényezóket, így a késôbbi negatív érzelmektôl, az anyasággal asszociált veszteségektôl való félelmet, aggodalmat tártak fel (Gillespie, 2003). 
Feltételezhetô, hogy ezek a motívumok összekapcsolhatóak a gyermekmentes személyeknél megfigyelt negatív emocionalitás értékkel és az esetükben megjelenô magasabb neuroticizmussal, hiszen a negatív érzelmekre való fogékonyság különösen érzékennyé teheti ôket ezekre az aggodalmakra, és facilitálhatja azt, hogy motivációs tényezôvé növekedjenek. Így tekintve a mozaikos információkra, az egyes kutatások az esetleges hiányosságok vagy interpretációt nehezítố tényezôk ellenére is szolgálhatnak az önkéntesen gyermektelenek személyiségének közelebbi ismeretéhez használható tartalommal.

Másrészt - és ezt elengedhetetlenül fontos hangsúlyozni - a személyiségjellemzók tekintetében született eddigi megfigyelések egyike sem igazán alkalmas ok-okozati összefüggések feltárására. Nem egyértelmú tehát, hogy a fentebb ismertetett jellemzókbôl következóleg döntenek-e a vizsgálati személyek a gyermekmentes életforma mellett, ahogy az sem egyértelmú, hogy anyává váló társaik személyiségét pontosan milyen irányban befolyásolja gyermekvállalásuk ténye, vagy maga a döntés, amely ezt megelőzi. Jokela, Kivimäki és Elovainio (2009) a személyiség és gyermekvállalás közötti kétirányú kapcsolattal kapcsolatos megközelítése ilyen szempontból kifejezetten érdekes. Ez alapján a szempont alapján belátható és feltárható különbségek adódhatnak a már szülôként nyilatkozó és a még gyermektelen, de gyermekre vágyó egyének lélektanában, így pedig a gyermekmentesektôl is más-más dimenziók mentén különbözhetnek. Érdemes lehet tehát újragondolt módszertani alapokra helyezni az elkövetkezô (hazai) kutatómunkát, és sokkal következetesebben elkülöníteni a gyermekre vágyó és már gyermeket vállalt személyek csoportjait egymástól.

Nem írja felül az iméntieket, de valamelyest árnyalja ezt a kérdéskört a genetikai és fejlôdéslélektani tényezôk kapcsán végzett kutatások némelyike. Figyelemre méltó Miller (1992, 2011) vonatkozó munkássága, aki az általa leírt tényezók közül a fertilitási vágyak szerepét emelte ki. Vizsgálatai alapján ezek közeli kapcsolatban állnak a reprodukciós motivációkat meghatározó genetikai komponensekkel, és feltehetôleg megannyi másik, a szülóket érintô motivációs és attitüdinális tényezôvel, ami a már megszületett gyermekek fejlôdésére is hatással van. Ily módon a fertilitási vágyakat egyfajta csatornának tekinti, melyen keresztül az emberi evolúció befolyásolja minden egyes újonnan születô gyermek adaptivitását és boldogságát. Saját fejlődéslélektani kutatásaival és Basten (2009) gondoskodási vággyal kapcsolatos gondolataival egybevetve úgy tûnik, megállapíthatunk a gyermekvállalási döntés szempontjából centrális személyiségjellemzóket vagy tulajdonságokat (fertilitási, illetve gondoskodási vágy) és mindketten evolúciós és genetikai alapokra mutatnak rá. Sejtethet ez egyfajta örökletességet, ugyanakkor Miller (2011) feltételezése szerint ezek az örökletes tényezôk nem csupán genetikai szinten jelennek meg az utódok életében, hanem a szülooi viselkedést meghatározó motívumok képében is. Ehhez mérten nehézkesen elkülöníthetôvé válhatnak az örökletes és környezeti tényezók.

Nem egyértelmú az sem, hogy milyen társadalmi tényezôk játszhatnak szerepet az önkéntesen gyermektelenek számának és társadalmon belüli arányának alakulásában. Különösen nôk esetében említhetô az a társadalmi átalakulási folyamat, mely az utóbbi évtizedekben Észak-Amerikában, Ausztráliában, valamint a legtöbb nyugatés észak-európai országban megjelenni látszik, amelynek következtében egyre több nô vállal munkát. Egyes feltételezések szerint a nôi életút átalakulása és egy, az aktív 
gyermekgondozással olykor nehezen vagy egyáltalán nem összeegyeztethetô karrierút lehetôségének a megjelenése hatással lehetett a gyermektelenség vagy gyermekmentesség társadalmi arányának változására. Érdekes lehetne a nyugati társadalmakétól eltérô kulturális adottságú országok populációjának behatóbb vizsgálata e tekintetben. Egy ehhez hasonló vizsgálat újabb lépést jelenthetne a kulturális-társadalmi, valamint személyiséglélektani hatások pontosabb elkülönítésében. Sajnos éppen a hagyományosabb nôi szerepeket preferáló társadalmakról van kevesebb információnk e tekintetben, így egyelôre kevés ilyen jellegú összehasonlításra kerülhetett sor.

Szociálpszichológiai implikációk tekintetében a leírt sztereotipikus tartalmak a fentebb körülírt okokból kifolyólag a nyugati társadalmak sajátosságai mellett kerültek felmérésre. Érdemes kiemelni, hogy egyes fejlôdő országokban akár radikálisan roszszabb lehet a helyzet, különösen a nók alapjogait még mindig vitató vagy nem elfogadó társadalmak esetén. Ugyanakkor nagy különbségek jelenhetnek meg egymáshoz területileg közelebbi nemzetek tagjainak véleményében is. A European Values Survey attitûdöt mérô kérdéssorainak eredményei és a vonatkozó hazai vizsgálatok (Pongrácz, 2007; Szalma és Takács, 2016) alapján például feltételezhetô, hogy Kelet-Európa és Kelet-Közép-Európa országainak népessége is kevéssé elfogadó az önkéntesen gyermektelenekkel kapcsolatban. Ezt az elképzelést látszanak alátámasztani a különbözô társadalmi sajátosságok mentén történô összehasonlítások. Ezek szerint az erôsen pronatalista társadalmakban, illetve az emberi fejlettségi indexen alacsonyabb pontszámot elérô országokban a gyermektelen válaszadók boldogtalanabbak és kevésbé elégedettek. Az erôsen pronatalista és egyben a népesség fenntartásához szükséges szintet meg nem haladó fertilitási rátával rendelkezô országokban élô gyermekmentesek szintén negatívabb tapasztalatokról adnak számot. Más megközelítések a nemi egyenlôség hatásával kapcsolatban arra világítanak rá, hogy alacsonyabb egyenlôségi szint esetén magasabb a gyermekmentesség elutasítottsága. Kérdés, hogy meghatározhatja-e mindez a nyugati társadalmakban leírtakhoz képest negatívabb vélekedés a társadalmi többség tagjainak a gyermektelen társaikkal való interakcióit, illetve (akár csak részben) ezeknek a hatásai nyilvánulnak-e meg a gyermekmentes személyek társadalmi sajátosságoktól függô, boldogságukkal és elégedettségükkel kapcsolatos beszámolóiban. Feltételezhetô, hogy ezek az egyedi tapasztalatok valamelyest más, akár kiterjedtebb képet festhetnek a gyermekmentes életformát választók mindennapi nehézségeiról.

Felmerülhet továbbá a nemi jellegzetességek felderítésének érdekében az önkéntesen gyermektelen férfiak pszichológiai sajátosságainak mélyebb vizsgálata. Lényegesen kevesebb vizsgálat foglalkozik behatóan személyiségjellemzóikkel, életútjaikkal és általában tapasztalataikkal. Ami pedig a megítélésüket illeti, a rendelkezésre álló adatok több esetben is ellentmondásosnak tûnnek a korábbi szakirodalmi eredményekkel szemben. Érdemes kiemelni például, hogy a nagyobb nemi egyenlôségú országokban ugyan átlagosan kisebb a gyermekmentesség elutasítottsága, de a kettôs elvárások szintje ezzel együtt magasabb - ráadásul a gyermekmentes férfiak kárára. Ezekben a társadalmakban nem a nôket ítélik meg szigorúbban gyermekmentességgel kapcsolatos döntésük miatt, hanem a férfiakat. Ezen túlmenóen korábbi vizsgálatok eredményei alapján bizonyos tekintetben negatívabban ítélik meg az önkéntesen gyermektelen férfiakat, újabb vizsgálatok pedig arra is rámutatnak, hogy az önkéntes gyer- 
mektelenség egyes országokban általában véve kevésbé elfogadott férfiak esetén. Kiemelten fontos lenne az eredmények szisztematikus vizsgálata, az egyéni és társadalmi tényezők, valamint az interszekcionális identitások figyelembevétele férfiak esetén is.

A heteroszexuálistól eltérô szexuális orientáció és a gyermekmentes életforma egybeesése, $\mathrm{s}$ az ehhez kapcsolódó társadalmi megítélés is érdekes és relatíve új kutatási terület, mely jelenleg még szinte alig kutatott. Homoszexuális egyének esetén egyrészt elmondható, hogy még mindig kevesebben válnak, illetve vágynak és terveznek a szülôvé válással heteroszexuális társaikhoz képest. Több, társadalmi helyzetükkel és személyes tapasztalataikkal kapcsolatos tényezô befolyásolja ilyen irányú döntésüket, melyeket egyrészt determinál közvetlen és tágabb értelemben vett társas közegük, másrészt nagyban meghatározza az is, hogy milyennek érzékelik ezt a közeget. Esetükben kiemelt fontossága lehet a különféle segítôprogramoknak, támogatócsoportoknak és egyéb, szülôvé válásukat segítô erőforrásoknak. Ezzel együtt igen speciális közösséget alkotnak a gyermektelenek csoportján belül is, hiszen sok esetben kiemelt jelentôsége lehet döntésük meghozatalában a gyermekvállalásukat nehezítô vagy akár ellehetetlenítô intézményeknek. Fontos lehet kiterjedtebb és mélyebb vizsgálatokat folytatni személyes tapasztalataik és heteroszexuális társaiktól eltérő életútjaik kapcsán. Náluk is kevesebb adat áll rendelkezésünkre a szexuális orientációjuk szempontjából kisebbségi helyzetben levố többi csoport kapcsán, így a késôbbi kutatási területek közül ez is kiemelt jelentôségú lehet. A téma szakirodalma nemcsak mélységében szorul kiegészítésre; a nemi szerepek és szexuális beállítottságok komplexitásának tárgyalásában is bôvítésre vár annak tartalma.

Ami a gyakorlati vonatkozásokat illeti, várható, hogy a gyermektelenség mellett határozók további vizsgálata társadalmi megítélésüket, s ezáltal pszichés jóllétüket is befolyásolhatja. Tágabb értelemben szólva a modern nemi szerepek és a szülơvé válás kapcsolatának a tradicionálistól eltérô, a gyermekteleneket stigmatizáló narratívája az összes gyermekmentes személyre hatással lehet. Ugyan demográfiai szempontok mentén egyértelmúnek tûnhet, hogy a gyermektelenség terjedése negatív irány, a nemzetközi tendenciák és a világ túlnépesedésének szempontjából a kérdés korántsem tûnik ilyen egyértelmúnek. A további vizsgálatok szükségessége éppen ezért megragadható a tudományos és közéleti szempontból egyaránt fontos témákra való figyelemfelhívásban is.

\section{IRODALOM}

Abma, J. C., \& Martinez, G. M. (2006). Childlessness among older women in the United States: Trends and profiles. Journal of Marriage and Family, 68(4), 1045-1056.

Ashburn-Nardo, L. (2016). Prenthood as a moral imperative? Moral outrage and the stigmatization of voluntarily childfree women and men. Sex Roles, 76, 393-401.

Avison, M., \& Furnham, A. (2013). Survey on personality and voluntary childlessness, carried out online May - July 2013. Letöltve: 2017.02.05-én: https://www.lauracarroll.com/wp-content/uploads/2016/11/Maggie-Personality-and-voluntary-childlessness-study-result-summary-Final.pdf

Avison, M., \& Furnham, A. (2015). Personality and voluntary childlessness. J Pop Research, 32, $45-67$. 
Basu, A. M. (2002). On the prospects for endless fertility decline in South Asia. In Population Bulletin of the United Nations, 48-49, 501-507.

Basten S. (2009). The socioanthropology of human reproduction. The future of human reproduction: working paper 1. University of Oxford and Vienna Institute of Demography.

Bays, A. (2016). Perceptions, emotions, and behaviors toward women based on parental status. Sex Roles, 76, 138-155.

Beaujouan, É., Sobotka, T., Brzozowska, Z., \& Zeman, K. (2017): Has childlessness peaked in Europe? Population E Societies, 540, 1-4.

Blackstone, A., \& Stewart, M. D. (2012). Choosing to be childfree: research ont he decision not to parent. Sociology Compass, 6, 1-10.

Bouchard, T. J., Jr., Lykken, D., McGue, M., Segal, N., \& Tellegen, A. (1990). Sources of human psychological differences: The Minnesota study of twins reared apart. Science, 250, 223-228.

Cannold, L. (2004). Declining marriage rates and gender inequity in social institutions: towards an adequately complex explanation of childlessness. People and Place, 12(4), 1-11.

Chamie, J., \& Mirkin, B. (2012). Childless by choice. YaleGlobal Online. Letöltve: 2017.08.25-én: https://www.yaleglobal.yale.edu/content/childless-choice

Dariotis, J. K. (2004). Fertility intention emergence, persistence and process during late adolescence and early adulthood: voluntary childlessness as a special case. Population Association of America 2004 Annual Meeting Program, Boston, MA: 2014. május 1-3.

Darling, N., \& Steinberg, L. (1993). Parenting Style as Context: An Integrative Model. Psychological Bulletin, 113(3), 487-496.

Doyle, J., Pooley, J. A., \& Breen, L. (2013). A phenomenological exploration of the childfree choice in a sample of Australian women. Journal of Health Psychology, 18(3), 397-407.

Else-Quest, N., \& Hyde, J. S. (2013). Half the human experience: The psychology of women. Belmont, CA: Wadsworth Publishing.

European Values Survey (1999). Percentage of people that think a woman has to have children in order to be fulfilled. Atlas of European Values. Letöltve: 2017.08.01-én: http:/ /www.atlasofeuropeanvalues.eu/new/wereld.php?ids=149\&year=1999

European Values Survey (2008). Percentage of people that agree or agree strongly with the statement that it is a duty towards society to have children. Atlas of European Values. Letöltve: 2017.08.01-én: http:/ / www.atlasofeuropeanvalues.eu/new/europa.php?ids=156\&year=2008

Földházi E. (2013). Magyarország népességének várható alakulása 2011-2060 között. Demográfia, 56(2-3), 105-143.

Gato, J., Santos, S., \& Fontaine, A. M. (2017). To have or not to have children? That is the question. Factors influencing parental decisions among lesbians and gay men. Sexuality Research and Social Policy, 14, 310-323.

GfK Roper (2008). A magyar nôk számára legfontosabb szeretteik biztonsága. Letöltve: 2017.02.01-én: http:/ /www.reklameszkoz.hu/gfk-roper-jelentes-magyar-nok

Gillespie, R. (2003). Childfree and feminine: Understanding the gender identity of voluntarily childless women. Gender and Society, (február), 122-136.

Gotlib, A. (2016). "But You Would Be the Best Mother": unwomen, counterstories, and the motherhood mandate. Bioethical Inquiry, 13, 327-347.

Hoem, J. M., Neyer, G., \& Andersson, G. (2006). Education and childlessness: The relationship between educational field, educational level, and childlessness among Swedish women born in 1955-59. Demographic Research, 14(15), 331-380.

Houseknecht, S. K. (1977). Reference group support for voluntary childlessness: Evidence for conformity. Journal of Marriage and Family, 39, 285-297.

Houseknecht, S. K. (1978). Voluntary childlessness: A social psychological model. Alternative lifestyles, 1(3), 379-402. 
Houseknecht, S. K. (1979). Timing of the decision to remain voluntarilychildless: Evidence for continuous socialization. Psychology of Women Quarterly, 4(1), 81-96.

Houseknecht, S. K. (1987). Voluntary childlessness. In Sussman, M. B., \& Steinmetz, S. K. (Eds), Handbook of marriage and the family (pp. 369-396). Boston, MA: Springer.

Jamison, P. H., Franzini, L. R., \& Kaplan, R. M. (1979). Some Assumed Characteristics of Voluntary Childfree Women and Men. Psychology of Women Quarterly, 4(2), 266-273.

Jokela M., Kivimäki M., Elovainio M., \& Keltikangas-Järvinen L. (2009). Personality and having children: a two-way relationship. Journal of Personality and Social Psychology, 96(1), 218-230.

Kanazawa, S. (2014). Intelligence and childlessness. Social Science Research, 48, 157-170.

Kelly, M. (2009). Women's voluntary childlessness: A radical rejection of motherhood? Women's Studies Quarterly, 37(3), 157-172.

Kiernan, K. E. (1989). Who remains childless. Journal of Biosocial Science, 21(4), 387-398.

Kiser, C. V. (1939). Voluntary and involuntary aspects of childlessness. The Milbank Memorial Fund Quarterly, 17(1), 50-68.

Kollega Tarsoly I. (1997). Magyarország a XX. században. II. kötet. Népesedéspolitika és népesedéselmélet. Szekszárd: Babits Kiadó.

Laegeforen, T. N. (2002). Voluntarily childless women - wherein lies the problem. Tidsskriftet, $122(1), 76-78$.

Letherby, G. (2002). Childless and Bereft: Stereotypes and Realities in Relation to Voluntary and Involuntary Childlessness and Womanhood. Sociological Inquiry, 72(1), 7-20.

Lunneborg, P. W. (1999). The chosen lives of childfree men. Westport, CT: Bergin és Garvey.

Martinez, G., Daniels, K., \& Chandra, A. (2012). Fertility of men and women aged 15-44 years in the United States: National survey of family growth, 2006-2010. National Health Statistics Reports, 51, Hyattsville, MD: National Center for Health Statistics.

Masebe, L., \& Ramosebudi, M. (2015). Trends and levels of childlessness among educated women in South Africa. African Population Studies, 30(2), 2897-2909.

McAllister, L. S., Pepper, G. V., Virgo, S., \& Coall, D. A. (2016). The evolved psychological mechanisms of fertility motivation: hunting for causation in a sea of correlation. Philosophical Transactions B, 371: 20150151., 1-16.

Miettinen, A., \& Szalma I. (2014). Childlessness intentions and ideals in Europe. Finnish Yearbook of Population Research, 49, 31-55.

Miller, W. B. (1992). Personality traits and developmental experiences as antecedents of childbearing motivation. Demography, 29(2), 265-285.

Miller, W. B. (2011). Differences between fertility desires and intentions: implications for theory, research and policy. Vienna Yearbook of Population Research, (Vol. 9), 75-98.

Mollen, D. (2006). Voluntarily childfree women: experiences and counselling considerations. Journal of Mental Health Counseling, 28(3), 269-284.

Newton, N. J., \& Stewart, A. J. (2013). The road not taken: Women's life paths and gender-linked personality traits. Journal of Research in Personality, 47(4), 306-316. Letöltve: 2017.04.08-án: https://www.ncbi.nlm.nih.gov/pmc/articles/PMC3613044/

Oroszné Perger M. (2002). A szülôi nevelési stílus. Iskolakultúra, 12(4), 107-114.

Park, K. (2002). Stigma management among the voluntarily childless. Sociological Perspectives, $45(1), 21-45$.

Pew Research Center (2015). Childlessness. Letöltve: 2017. 08.19-én: http:/ / www.pewsocialtrends. org/2015/05/07/childlessness/

Plomin, R. (1990). The role of inheritance in behavior. Science 248(April), 183-88.

Pongrácz T. (2007). A gyermekvállalás, gyermektelenség és a gyermek értéke közötti kapcsolat az európai régió országaiban. Demográfia, 50(2-3), 197-219.

Popenoe, P. (1936). Motivation of childless marriages. The Journal of Heredity, 17(12), 469-472. 
Popenoe, P. (1943). Childlessness: Voluntary or involuntary? The Journal of Heredity, 34, 83-87.

Reynolds, E., \& Macomber, D. (1924). Fertility and sterility in human marriages. Philadelphia: W. B. Saunders Company.

Richie, C. (2013). Voluntary sterilization for childfree women: Understanding, patient profiles, evaluating accessibility, examining legislation. Hastings Center Report, 43(6), 36-44.

Rijken, A. J., \& Merz, E. M. (2014). Double standards: Differences in norms on voluntary childlessness for men and women. European Sociological Review, 30(4), 470-482.

Russo, N. F. (1976). The motherhood mandate. Journal of Social Issues, 32, 143-153.

S. Molnár E. (2009). A gyermekszám-preferenciák alakulása Magyarországon az elmúlt évtizedekben. Demográfia, 52(4), 283-312.

Slauson-Blevins, K., \& Johnson, K. M. (2016). Doing gender, doing surveys? Women's gatekeeping and men's non-participation in multi-actor reproductive surveys. Sociological Inquiry, $86(3), 427-449$.

Szabó L. (2015). Terjed a gyermektelenség Magyarországon. A fốvárosi nốk egyötöde gyermek nélkül éli le életét. Korfa, 15(1), 1-4. Letöltve: 2017. 08. 01-én: http://demografia.hu/kiadvanyokonline/index.php/korfa/article/view/1299/734

Szalma I. (2010). Attitûdök a házasságról és a gyermekvállalásról. Demográfia, 53(1), 38-66.

Szalma I., \& Takács J. (2012). A gyermektelenséget meghatározó tényezốk Magyarországon. Demográfia, 55(1), 44-68.

Szalma I., \& Takács J. (2016). Gyermektelenség Magyarországon: Mítoszok és kutatási eredmények. Magyar Tudomány, 177(2), 159-167.

Tanaka, K., \& Johnson, N. E. (2016). Childlessness and mental well-being in a global context. Journal of family issues, 37(8), 1027-1045.

Tárkányi Á. (2008). A második demográfiai átmenet néhány fő̉bb tényezője a fejlett világban és Magyarországon. Demográfia, 51(4), 406-440.

Thornton, A., \& Young-DeMarco, L. (2001). Four decades of trends in attitudes toward family issues in the United States: The 1960s through the 1990s. Journal of Marriage and Family, 63(4), 1009-1037.

Veevers, J. (1972). The violation of fertility mores: Voluntary childlessness as deviant behavior. In Boydell, C., Grinstaff, C. \& Whitehead, P. (Eds), Deviant behavior and societal reaction (pp. 571-592). Toronto: Holt, Rinehart and Winston.

Veevers, J. (1973). Voluntary childlessness: A neglected area of family study. The Family Coordinator, 22(2), 199-205.

Veevers, J. (1974). Voluntary childlessness and social policy: An alternative view. The Family Coordinator, 23(4), 397-406.

Veevers, J. (1975). The moral career of voluntarily childless wives: notes on the defense of a variant world view. Family Coordinator, 24, 473-487.

Waren, W., \& Pals, H. (2013). Comparing characteristics of voluntarily childless men and women. Journal of Populational Research, 30(2), 151-170.

Web ofScience (2018). 1971 és 2018közöttmegjelent cikkekidôbeli eloszlása. Letöltve:2018.09.24én: http://apps.webofknowledge.com/CitationReport.do?product=WOS\&search_mode= CitationReport\&SID=F4Grm7ILaRLvTT8a1jg\&page=1\&cr_pqid=2\&viewType=summary 


\section{PSYCHOLOGY OF VOLUNTARY CHILDLESSNESS: LITERATURE REVIEW}

\section{KIS, ANDREA}

This theoretical study summarizes the results of major research papers on psychological and sociological aspects of voluntary childlessness with respect to both international and domestic circumstances. To this end, I mainly looked at studies available in English-language databases using a systematic keyword search method, but I also relied on the Hungarian literature.

This topic is one of the important and diverse elements of social change today, however it is a peripheral phenomenon. It is scarcely present in Hungarian scientific literature, while in international literature it is very mosaic - there are great time and spatial differences between the publication of each related study. For this reason, one purpose of this paper is to take a more uniform approach to these issues, and summarize knowledge not only on the topic itself, but also on the present situation of the research of this topic.

A clear conclusion derived from the literature seems to be that the decidedly childless form a special group within childless individuals, one without homogeneity, yet they could be distinctly differentiated from others due to some specific psychological and socio-demographic characteristics they do share. However, it is difficult to set up categories within this group, and even opinions on the exact conceptual background are divided. It can also be said that in Hungary the research of the phenomenon is in its infancy - Hungarian authors have so far primarily studied the phenomenon using a sociological or demographic approach.

The small number of research aimed at revealing the psychological cause-effect mechanisms and the fragmentation of their results also make it difficult to derive conclusions about the personality and developmental psychological aspects of the subject. The examination of the possibilities of accepting choices of childlessness as alternative lifestyles instead of interpretations as deviance within pronatalist societies and exploring the possibilities of abolishing stigmas are less-researched, although some studies raise the need for such actions.

Overall, the main goal of the study is to present the above-described outcomes andfor further psychological research related to this topic.

Keywords: voluntary childlessness, childbearing, childbearing attitudes, childfree, motherhood role 